\title{
O polskim wydaniu Liberum Arbitrium Francesca Negriego i ,zagranicznej” pochwale polskich pisarzy reformacyjnych*
}

Zarys treści: W artykule podjęto problem atrybucji wydania utworu Liberum Arbitrium Francesca Negriego da Bassano z 1559 r. z adresem „Pesclavii”, zawierającego wzmianki o polskich pisarzach reformacyjnych (Andrzeju Trzecieskim, Mikołaju Reju), których brak w wydaniu z tego samego roku tłoczonym przez Jeana Crespina w Genewie. Druk przypisano oficynie Daniela z Łęczycy, rozpoznając zafałszowanie adresu wydawniczego jako element reformacyjnej propagandy wydawniczej.

\begin{abstract}
The article deals with the problem of attribution of the 1559 edition of Liberum Arbitrium by Francesco Negri da Bassano with the 'Pesclavii' address, containing references to some Polish Reformation writers (Andrzej Trzecieski, Mikołaj Rej), that are missing from the same year edition pressed by Jean Crespin in Geneva. The printing was attributed to the Daniel of Łęczyca publishing house, recognising the falsification of the publishing address as an element of Reformation publishing propaganda.
\end{abstract}

Słowa kluczowe: Daniel z Łęczycy, Pińczów, reformacja, historia książki, typografia nowożytna, Mikołaj Rej, Andrzej Trzecieski

Keywords: Daniel of Łęczyca, Pińczów, Reformation, book history, early modern typography, Mikołaj Rej, Andrzej Trzecieski

Aleksander Brückner zwracał uwagę na pochodzące z 1559 r. wydanie utworu Liberum Arbitrium pióra Francesca Negriego da Bassano (1500-1563), włoskiego pisarza i myśliciela religijnego osiadłego w Szwajcarii ${ }^{1}$. Z kilku względów jest ono szczególnie interesujące dla czytelnika polskiego. Adresatem dedykacji jest Mikołaj Radziwiłł „Czarny”, opiekun i protektor reformacji w Wielkim Księstwie Litewskim. W jej treści wzmiankowany jest także Traiano Provana (Trajan Prowana), mieszkający w Krakowie Włoch, który został przedstawiony jako pośrednik pomiędzy Negrim a Radziwiłłem. W tekście tragedii, jak spostrzegł A. Brückner, znajdują się wzmianki o jeszcze dwóch polskich autorach związanych z protestantyzmem: Mikołaju Reju oraz Andrzeju Trzecieskim. Książka nosi adres wydawniczy „Pesclavii 1559”, co uczony przyjął i potraktował jako polonicum odbite na prasach w Poschiavo

\footnotetext{
* Praca naukowa finansowana ze środków budżetowych na naukę w latach 2017-2021 jako projekt badawczy w ramach programu „Diamentowy Grant”. Za uwagi do artykułu dziękuję anonimowym Recenzentom. Za lekturę i konsultację koncepcji całego tekstu chciałbym także podziękować dr Izabeli Wiencek-Sielskiej z Gabinetu Starych Druków Biblioteki Uniwersyteckiej w Warszawie oraz Barbarze Dzierżanowskiej z Zakładu Starych Druków BN.

1 Zob. A. Brückner, Mikołaj Rej. Studium krytyczne, Kraków 1905, s. 85-86; tenże, Drobiazgi krytyczne, „Prace Filologiczne”, 6, 1907, s. 161-164; zob. też K. Estreicher, Bibliografia polska, t. 23, Kraków 1909, s.v. Niger Franciszek Bassanensis, s. 153.
} 
w szwajcarskiej Gryzonii. A. Brückner uznał to więc za przejaw sławy polskich zwolenników reformacji, których pochwałę zawierał druk rozpoznany jako szwajcarski.

Wiadomo, że A. Brückner korzystał z egzemplarza do dziś znajdującego się w zbiorach Biblioteki Jagiellońskiej² ${ }^{2}$ We współczesnym katalogu książnicy adres wydawniczy „Poschiavo” uznano jednak za fałszywy, a druk przypisano rodzimej, krakowskiej oficynie dziedziców Marka Szarfenberga, opatrując tę atrybucję znakiem zapytania i akceptując podaną datę ${ }^{3}$ Przyczyny tej decyzji nie zostały jednak wyjaśnione. Warto się zastanowić, czy jest to jedyna możliwość atrybucji i rozważyć inne prawdopodobieństwa przypisania tego druku (poza oficyną dziedziców Szarfenberga są to: Jan Karcan, Łazarz Andrysowic oraz Daniel z Łęczycy), a także wskazać na tekstowe różnice występujące w treści utworu i jego paratekstach ${ }^{4}$ pomiędzy wersją utrwaloną w badanym wydaniu oraz wydaniami zagranicznymi. Poczynione rozpoznania pozwolą dopełnić ogląd reformacyjnego programu wydawniczego w Polsce oraz transmisji wzorców literackich służących propagandzie konfesyjnej doby wczesnonowożytnej.

\section{Wydania utworu do 1559 i różnice tekstowe między edycjami lacińskimi z 1559 r.}

Utwór Negriego miał stosunkowo wiele wydań w kilku językach: trzy po włosku (czyli języku oryginału), a także po dwa w przekładzie francuskim i łacińskim. Po raz pierwszy wersję włoską wydano w 1546 r. jako Tragedia di F.N.B. intitolata Libero Arbitrio ${ }^{5}$. Wydawca ukrył autora pod inicjałami. Pozbawiony adresu wydawniczego druk przypisuje się bazylejskiej oficynie Johanna Oporina ${ }^{6}$. Pięcioaktowy utwór formalnie przypomina raczej dialog ze względu na nikłą akcję, ale całość nazwano tragedią, zapewne chcąc oddać za pomocą tego terminu fabularną konstrukcję tekstu, składającego się z następujących po sobie sekwencji wydarzeń, a nie tylko sytuację rozmowy i treść konwersacji. Rzecz dzieje się w mieście przypominającym Rzym, w podlegającym papieskiej jurysdykcji królestwie rządzonym przez króla Libero Arbitrio. Fikcyjne postaci alegoryczne zostały w nim przemieszane z bohaterami historycznymi. Początkowe rozmowy z postaciami dworu fikcyjnego królestwa, inicjowane przez balwierza imieniem Bertuccio, służą zarysowaniu geografii fikcyjnego królestwa, jego miast i prowincji, będących symbolicznym wyrazem rozmaitych przewin przypisywanych przez reformatorów Kościołowi rzymskiemu. W akcie czwartym do królestwa przybywają apostołowie Piotr i Paweł, którzy przerażeni tym, co zastali, wygłaszają przemowy wyjaśniające, jak powinno wyglądać prawdziwe chrześcijaństwo, a ich wizja jest zgodna z postulatami reformacji. Wreszcie $\mathrm{w}$ akcie piątym nieokreślony papież zostaje

2 Zob. A. Brückner, Drobiazgi, s. 162. Mowa o egzemplarzu BJ, sygn. St. Dr. Cim. 5201.

${ }^{3}$ Zob. Catalogus librorum saeculi XVI qui in Bibliotheca Iagellonica Cracoviensi asservantur, t. 5, red. M. Malicki, Baden-Baden 2004, s. 301, nr N-87. Za atrybucją krakowskich bibliotekarzy idzie także autor bibliografii Negriego, zob. L. Ragazzini, Francesco Negri, Baden-Baden 2006, s. 80. To samo przypisanie druku dziedzicom Szarfenberga można także odnaleźć w Centralnym Katalogu Poloników XVI wieku w BN. W bibliotekach polskich znajduje się pięć egzemplarzy tego druku. Autor artykułu konsultował egzemplarze w BCzart. (sygn. 2412 II Cim), BJ (St. Dr. Cim. 5986 oraz St. Dr. Cim. 5201) i BUWr. (sygn. 401049). Nie konsultowano egzemplarzy Biblioteki Gdańskiej PAN (sygn. Cz.7199.8º informacja z Centralnego Katalogu).

${ }^{4}$ Przez paratekst rozumiem zestaw elementów tekstowych (np. dedykacje, marginalia) stanowiących otoczenie właściwego tekstu w obrębie materializacji utworu, jaką jest książka. O zastosowaniu terminu do książki dawnej zob. I. Winiarska-Górska, Szesnastowieczne przekłady Pisma Świętego na język polski (1551-1599) jako gatunek nowożytnej książi formacyjnej, Warszawa 2017, s. 53-54, 129-168; Renaissance Paratexts, red. H. Smith, L. Wilson, Cambridge 2011. Zbliżonym terminem jest „literacka rama wydawnicza” sformułowana przez R. Ocieczek (Rama utworu, w: Stownik literatury staropolskiej, red. T. Michałowska, Wrocław 1990, s. 684-688).

5 VD16: ZV 11429 (skrótem VD16 zgodnie z ogólnie przyjętą konwencją oznaczam druki odnotowane w Verzeichnis der im deutschen Sprachbereich erschienenen Drucke des 16. Jahrhunderts, <www.vd16.de> [dostęp: 19.05.2021]). Na temat utworu oraz historii jego wydań zob. F. Zonta, Francesco Negri l'eretico e la sua tragedia „Il libero arbitrio”, „Giornale storico della letteratura italiana", 67, 1916, nr 1, s. 265-324, 68, 1916, nr 2, s. 108-160; E. Barbieri, Note sulla fortuna della "Tragedia del libero arbitrio” di F. Negri da Bassano, „Bolletino della Società di Studi Valdesi”, 181, 1997, s. 107-141; L. Ragazzini, Francesco Negri, s. 73-77.

${ }^{6}$ L. Ragazzini, Francesco Negri, s. 79. 
rozpoznany jako Antychryst, a podległy mu król skazany na śmierć. Sądu nad nim i egzekucji dokonują archanioł Rafał (Angelo Raphaele) i personifikacja łaski (Gratia Giustificante).

Niedługo po pierwszym wydaniu tekst został przedrukowany przypuszczalnie przez weneckiego drukarza Antonia Bruciolego w 1547 r. $^{7}$ Kolejne wydanie nosi datę 1550 i choć wskazuje autora, to nie nazwisko drukarza ${ }^{8}$. Edoardo Barbieri przypuszcza, że mogło zostać wydrukowane w Bazylei, podobnie jak pierwodruk ${ }^{9}$. Karta tytułowa informuje, że jest to wydanie drugie, poszerzone („,editione seconda, con accrescimento"). Jedną ze zmian jest również uzupełnienie utworu o obszerny autorski wstęp (,al christano lectore salute”), w którym Negri wskazuje na przyświecającą mu chęć odmalowania za pomocą tragedii ,ppapieskiego królestwa Antychrysta”, krytykuje toczące się obrady soboru trydenckiego i wskazuje na głównych włoskich zwolenników ruchu reformacyjnego (Piera Paola Vergeria, Bernardina Ochina) ${ }^{10}$. Różnice między pierwodrukiem a wydaniem poszerzonym, zgodnie z zapowiedzią strony tytułowej, polegają przede wszystkim na rozbudowaniu w utworze niektórych kwestii, uzupełnieniu argumentacji, a czasem dopisaniu nowych scen (przy bardzo nielicznych redukcjach tekstu) ${ }^{11}$.

Następnie po utwór sięgnął w 1558 r. typograf genewski Jean Crespin, przygotowując wydanie przekładu francuskiego, który ukazał się jako Tragedie du Roy Franc-arbitre, nouvellement traduite d'Italien en François ${ }^{12}$. Autor nie został w nim wskazany z imienia. Znane jest także o rok późniejsze wydanie w języku francuskim, ozdobione sygnetem Crespina i oznaczone adresem wydawniczym Villefranche, uznaje się jednak te informacje wydawnicze za sfingowane. Ponieważ genewski drukarz był jednym z głównych dostarczycieli francuskojęzycznych tekstów reformacyjnych, pod jego oficynę podszywał się w latach 1559-1562 również normandzki typograf Pierre Philippe z Caen i to on przedrukował francuską wersję utworu Negriego ${ }^{13}$.

W 1559 r. już niewątpliwie Crespin wydał w Genewie kolejny, tym razem łaciński przekład tragedii $^{14}$. Tłumaczenie opracowano na podstawie poszerzonej wersji utworu z $1550 \mathrm{r}$. Karta tytułowa wskazuje, że przekład sporządził Negri (,nunc primum ab ipso authore latine scripta et edita”) (Aneks 1, il. 1). Wydanie to zawiera prozatorską dedykację skierowaną do Mikołaja Radziwiłła. Bardzo podobnie brzmiąca dedykacja - choć różniąca się w szczegółach - znalazła się w drugim wydaniu opatrzonym datą 1559, czyli przywołanym wcześniej druku noszącym adres wydawniczy „Pesclavii”, który opisywał A. Brückner ${ }^{15}$.

W owym wydaniu sine nomine z 1559 r. (które dalej będzie tu określane jako „wydanie anonimowe" ze względu na brak wskazania drukarza, choć nazwisko autora nie zostało ukryte; Aneks 1, il. 2) zastosowany materiał typograficzny (dominuje antykwa) różni się od edycji genewskiej (przeważa kursywa). Inny był także zastosowany format: druk Crespina to octavo liczące 138 kart (A-R ${ }^{8}$, a anonimowy - quarto na 122 kartach $\left(\mathrm{a}^{4}, \mathrm{~A}-\mathrm{Z}^{4}, \mathrm{a}-\mathrm{g}^{4},[2] \mathrm{k}.\right)$. Co jednak najistotniejsze, oba wydania zawierają nieduże, ale znaczące różnice w przekazywanym tekście. Są to: różnice w poprzedzających

\footnotetext{
${ }^{7}$ Zob. E. Barbieri, Note, s. 120-123. O miejscu druku świadczy m.in. list Ottaviana della Rovere do kardynała Marcella Cerviniego z 4 I 1547 (przedruk w: G. Buschbell, Reformation und Inquisition in Italien um die Mitte des XVI. Jahrhunderts, Paderborn 1910, s. 244-245); zob. też D. Wahrman, From Imaginary Drama to Dramatized Imagery. The Mappe-Monde Nouvelle Papistique, 1566-67, „Journal of the Warburg and Courtauld Institutes”, 54, 1991, s. 191.

8 VD16: N 467.

${ }^{9}$ E. Barbieri, Note, s. 125-126. Z kolei L. Ragazzini (tenże, Francesco Negri) nie notuje tego wydania. Egzemplarz znajduje się np. w monachijskiej Bayerische Staatsbibliothek, sygn. P.o.it. 694.

${ }^{10}$ F. Negri, Della tragedia [...] intitolata Libero Arbitrio, [Bazylea] 1550, k. A 1 v- $\mathrm{B}_{8} \mathrm{r}$.

${ }^{11}$ Różnice między wydaniami zostały odnotowane w edycji krytycznej włoskiej wersji utworu; zob. F. Negri da Bassano, Tragedia intitolata Libero Arbitrio, 1546 | 1550, oprac. C. Casalini, L. Salvarini, Roma 2014.

12 J.F. Gilmont, Bibliographie des éditions de Jean Crespin, 1550-1572, t. 1, Verviers 1981, s. 103-104, nr 58/14.

${ }_{13}$ A. Pettegree, The French Book and the European Book World, Leiden 2007, s. 47; zob. też J.F. Gilmont, Bibliographie, s. $118-119$, nr $59 / 9 *$.

14 J.F. Gilmont, Bibliographie, s. 118, nr 59/9; zob. też Les livres imprimés a Genève de 1550 a 1600, red. P. Chaix, A. Dufour, G. Moeckli, Genève 1966, s. 39.

15 Pierwszy dokładny opis wydania anonimowego znajduje się w: S. Ciampi, Bibliografia critica delle antiche reciproche corrispondenze politiche, ecclesiastiche, scientifiche, letterarie, artistiche dell'Italia colla Russia, colla Polonia ed altre parti settentrionali, t. 2, Firenze 1839, s. 3-5.
} 
utwór zwrotach do czytelnika, modyfikacje wprowadzone w dedykacji oraz dwie partie tekstu (przytoczone poniżej) umieszczone w wydaniu anonimowym, lecz nie w edycji genewskiej. Ponadto wydanie anonimowe zamyka niewystępująca u Crespina obszerna łacińska parafraza Psalmu 104(103) adresowana do „odrodzonego” Kościoła w Polsce $\left(\mathrm{k} \mathrm{G}_{4} \mathrm{r}\right)$.

Poza adresem wydawniczym w obu omawianych wydaniach oznaczonych jako 1559 różni się układ początkowych paratekstów. W druku Crespina na odwrocie karty tytułowej $\left(\mathrm{a}_{1} \mathrm{v}\right)$ umieszczono wierszowany zwrot Negriego do czytelnika, a dedykacja do Radziwiłła rozpoczyna się na kolejnej stronie (dalej określana w żywej paginie jako Epistola $)^{16}$. W wydaniu anonimowym można ją również odnaleźć na karcie a $\mathrm{r}$ (choć wydrukowaną bez żywej paginy), lecz strona recto karty tytułowej pozostała pusta. Apostrofa Georgius Niger Bassanensis ad Lectorem de Libello - wprawdzie niezmieniona - następuje dopiero po liście dedykacyjnym skierowanym do litewskiego magnata $\left(\mathrm{k}\right.$. $\left.\mathrm{a}_{4} \mathrm{v}\right)$. Ponadto uzupełniona została o niewystępujący w genewskim druku dwuwiersz wraz z tytułem:

\section{Eiusdem [tj. Francesca Negriego - W.K.] ad Libellum}

I, liber, audacter, quo ferre Georgius audet

Te Niger ac metuas pro pietate nihil ${ }^{17}$.

Poza drobnymi zmianami stylistycznymi lub korektami dedykacje w obu drukach różnią się przyjętą grafią (w wydaniu genewskim np.: „negocia”, „coelestis”, „coeperunt”, ,authores”; w wydaniu anonimowym: „negotia”, „caelestis”, „caeperunt”, ,auctores”) oraz nielicznymi przestawieniami szyku zdań. Nie są to istotne różnice poza bodaj jednym szczególnym przypadkiem. U Crespina zwrot otwierający dedykację brzmi (w transliteracji): „Illustrissimo [...] Nicolao Radziuil, Duci in Olika \& Nijessuies”. W wydaniu anonimowym zapisano go w istotnie odmienny sposób: „Ilustrissimo [...] Nicolao Radzivvil, Duci in Olyka \& Niesuesz”. Niektóre zmiany graficzne w tej frazie (zastosowanie podwójnego „," na oznaczenie twardej głoski „w”, obniżenie artykulacji samogłoski „,i” do „,y” oraz zapis nazwy miejscowej Nieśwież z miękkim „ni” na początku bez nieznanego polszczyźnie w wyrazach rodzimych wzdłużenia przed samogłoską i z dwuznakiem „sz” na końcu) z dużym prawdopodobieństwem wskazują na posługującego się językiem polskim zecera lub korektora, podczas gdy zapis zastosowany w wydaniu genewskim stanowi fonetyczne uproszczenie dźwięków polskich nieoddawanych w łacinie. Szczegół ten uprawdopodabnia hipotezę postawioną w katalogu Biblioteki Jagiellońskiej o tłoczeniu wydania anonimowego w Polsce.

Spośród zmian stylistycznych uwagę zwraca najobszerniejsza modyfikacja w partii dedykacyjnej skierowanej do Radziwiłła, która polega na użyciu odmiennych sformułowań określających wspominane osoby:

[Wydanie genewskie:] Huius igitur et syncerae pietatis, et excellentis praestantiae tuae certam exploratamque notitiam quum rumor minime dubius authore in primis Traiano Provana consiliario istic Regio et virtutibus omnibus ornatissimo et tui studiosissimo viro, ad nos etiam pertulisset, illico nostrates quoque te non iniuria et suspicere et admirari magnopere coeperunt [podkr. W.K.] ${ }^{18}$.

\footnotetext{
${ }^{16} \mathrm{O}$ patronacie magnackim nad reformacją w świetle drukowanych listów dedykacyjnych pisze, nie wspominając jednak o omawianym tu przypadku, M. Jarczykowa, Obraz świeckich patronów i seniorów Kościoła ewangelicko-reformowanego w piśmiennictwie XVI-XVII wieku, „Terminus”, 19, 2017, nr 43, z. 2, s. 253-276; zob. też K. Górski, W promieniach mecenatu Mikołaja Radziwitła Czarnego, w: tenże, Studia nad dziejami polskiej literatury antytrynitarskiej XVI wieku, Kraków 1949, s. 101-140. Ogólnie o funkcjach listów dedykacyjnych w książce wczesnonowożytnej zob. A. Czekajewska, Kultura umystowa Polski XVI wieku w świetle listów dedykacyjnych, „Studia i Materiały z Dziejów Nauki Polskiej. Seria A”, 7, 1965, s. 48-109; o aktorach sieci wytwórstwa dawnej książki na podstawie listów dedykacyjnych zob. taż, O listach dedykacyjnych w polskiej książce XVI wieku, „Roczniki Biblioteczne”, 6, 1962, s. 22-55.

${ }^{17}$ F. Negri, Liberum Arbitrium tragoedia, Pesclavii: [s.n.], 1559, k. A A. W przekładzie: „Idź, książko, odważnie, dokąd Georgius odważa się nieść / Ciebie Niger i nic nie martw się o pobożność" (tłum. Martyna Osuch).

18 Tenże, Liberum Arbitrium tragoedia, [Genewa] 1559, s. 6.
} 
[Wydanie anonimowe:] Huius igitur et syncerae pietatis, et excellentis praestantiae tuae certam exploratamque notitiam quum rumor minime dubius authore in primis Magnifico Viro Domino Traiano Provana Sacrae Regiae Maiestatis dignissimo Secretario, nec non Celsitudinis tuae addictissimo ad nos etiam pertulisset, illico Nostrates quoque te non iniuria et suspicere et admirari maxime caeperunt [podkr. W.K.] ${ }^{19}$.

Podkreślone zmiany mają charakter głównie honoryfikatywny. Dodano określenie Provany jako „wspaniałego męża i pana”, sprecyzowano także jego rolę na dworze królewskim i tytulaturę monarchy, którego Włoch był sekretarzem („Sacrae Regiae Maiestatis [...] Secretatario”) ${ }^{20}$. W genewskim wydaniu Provana został określony raczej ponad faktycznie pełnioną funkcję jako „doradca tegoż króla” („,consiliario istic Regio"). Ponadto uwypuklono w wydaniu anonimowym przywiązanie Włocha do Radziwiłła (,addictissimus” zamiast wcześniejszego „studiosissimus”), mianując przy tym wojewodę wileńskiego „wysokością” („Celsitudinis tuae”). Znamienne, że określenie to („celsitudo”) nie pojawia się więcej w tekście dedykacji poza owym dodatkiem anonimowego wydania. Można by wysunąć przypuszczenie, że korekt tych dokonała osoba, której zależało na właściwym utytułowaniu wzmiankowanych osób wysokiego szczebla, Zygmunta Augusta i Radziwiłła: zarówno by pozyskać ich łaski, jak i ustrzec się uchybienia godności. Superlatywy zaś opisujące Provanę, jego cnoty i uczoność, sprowadzone zostały do bardziej konwencjonalnego epitetu („magnificus vir”) i precyzyjniejszego wskazania funkcji. Uniknięcie niepotrzebnego wywyższenia wobec króla leżałoby tak w interesie samego Włocha, jak i całego środowiska ewangelickiego w Małopolsce, z którym mógł być kojarzony (z 1559 r. pochodzi świadectwo jego uczestnictwa w protestanckim synodzie w Pińczowie, a rok wcześniej jego brat Prospero prosił synod w Książu w imieniu obu o przydzielenie domowego kaznodziei) ${ }^{21}$. Związki Traiana i jego brata Prospera z Negrim są jednak potencjalnie głębsze: Giorgio Negri (Georgius Niger), syn autora tragedii, przybył do Polski w 1557 r. i od synodu w Książu, który odbył się rok później, pełnił funkcję domowego ministra obu braci (choć nie wiadomo, jak długo) ${ }^{22}$. Nie można jednak stwierdzić, że Provana odpowiadał za wprowadzone modyfikacje.

Kolejne dwie zmiany występują w treści utworu i mają inny charakter niż poprawki wprowadzone do listu dedykacyjnego - stanowią bowiem amplifikację tekstu o niewystępujące tam wcześniej fragmenty. Wzmiankę o Trzecieskim niewystępującą w druku Crespina napotka czytelnik w wydaniu anonimowym w drugiej scenie aktu II, w której rozmawiają balwierz Bertucius (uznawany za porte-parole Negriego), skryba Amonius, notariusz Tripho oraz Actus Elicitus, personifikacja występująca w roli doradcy tytułowego króla Liberum Arbitrium. Rozmowa na temat prowincji składających się na Królestwo Dobrych Uczynków (Bonorum Operum Regnum) wywiązuje się przy okazji zgłoszonej przez skrybę potrzeby weryfikacji kancelaryjnych dokumentów. Opis prowincji „mnichów” (Monachatus) jest pretekstem do formułowania zarzutów wobec hipokryzji życia zakonnego i rozwijania obrazu rozpustnego życia zakonników, co przedstawiono w ramach obranej konwencji jako udokumentowany stan regionu wyimaginowanego królestwa. Balwierz, przysłuchujący się głośnej lekturze owych deskrypcji, komentował je ze zdziwieniem i kwestionował ich słuszność. W jednej z takich wypowiedzi przywołał Lukana (Pharsalia, ks. X, w. 407), zamieniając jednak ,żołnierskie obozy” („castra”) na „klasztory”: „Nulla fides pietasque viris qui claustra sequuntur" (k. 23v), tym samym przypisując bezbożność zgromadzeniom

${ }^{19}$ F. Negri, Liberum, Pesclavii 1559, k. A2r.

${ }^{20} \mathrm{Na}$ temat braci Provanów zob. D. Quirini-Popławska, Provana Prospero, w: PSB, t. 28, Wrocław 1985, s. 526-529; taż, Provana Traiano, w: PSB, t. 28, Wrocław 1985, s. 529-530; taż, Działalność Włochów w Polsce w I połowie XVI wieku na dworze królewskim, w dyplomacji i hierarchii kościelnej, Wrocław 1973, s. 13, 102. Jako sekretarz królewski występuje Provana tylko raz w MK we wpisie z 26 VII 1558 (M. Korolko, Seminarium Rzeczypospolitej Królestwa Polskiego. Humaniści w kancelarii królewskiej Zygmunta Augusta, Warszawa 1991, s. 230), choć możliwe, że pełnił tę funkcję w 1559 r., na co pośrednio wskazuje redakcja dedykacji anonimowego wydania. Nie wydaje się jednak, aby zmiana w stosunku do wydania genewskiego podyktowana była zmianą statusu Provany między oboma wydaniami, a raczej brakiem precyzji autora pierwotnej wersji dedykacji.

${ }^{21}$ Akta synodów różnowierczych w Polsce, t. 1: 1550-1559, oprac. M. Sipayłło, Warszawa 1966, s. 310 (zjazd synodalny w Pińczowie 7 VIII 1559); D. Quirini-Popławska, Provana Prospero, s. 528.

22 D. Quirini-Popławska, Provana Prospero, s. 529. 
zakonnym. Actus Elicitus wskazał na poprawne brzmienie wersetu u Lukana, lecz Bertucius upierał się, że taką lekcję tekstu znalazł w swojej książce. W wydaniu anonimowym do wypowiedzi balwierza dodano następujący fragment:

Neque enim adduci possum, ut credam, mendum inesse codici, qui mihi ex Andreae Tricesii et nobilitate et eruditione praestantissimi Equitis bibliothecae dono sit missus, quum ingenuus et pius Is adolescens, triumque linguarum peritissimus erratum aliquod suos commaculare libros aequo animo non sustinuisset. Non possum me continere quandoquidem in Iuvenis huius egregii mentionem incidimus, quin tibi recitem hic Oden quandam brevem quidem illam, sed non prorsus inconcinnam, qua singularis eius amicus hunc olim ipsum verae gloriae commendavit, his verbis:

Sunt qui celsa petant iuga

Parnasi placidas pieridum domos,

Fiant inter ut inclyti

Mortaleis, celebrant carmine quos suo.

At splendore Tricesius

Contentus proavorum, ac proprio simul,

Haec vanissima respuens

(Quanquam sustineat clarum Equitem lubens

Tergo Pegasus hunc suo)

Virtute eximia, moribus optimis

Ac linguis pariter tribus

Ornatus, quibus est et pietas comes,

Coelum stelliserum petit,

Dignis ut celebret numina laudibus.

Verum tu, Tripho, iam sequere ${ }^{23}$.

Bertucius wskazuje w przytoczonym fragmencie, że książka z owym zmienionym brzmieniem wersetu Lukana miałaby pochodzić z księgozbioru Andrzeja Trzecieskiego. Doprowadziło to niektórych do przekonania, że Polak istotnie posiadał jakiś egzemplarz Lukana z tak zmodyfikowanym tekstem ${ }^{24}$. Choć nie można wykluczać, że pamflet będący przeróbką z Lukana krążył gdzieś w kręgach różnowierczych, to pewne jest, że wzmianka o bibliotece Trzecieskiego stanowi tu jedynie dodatek anonimowego wydawcy. W istocie docinki oparte na grze słownej nieustannie powracają w utworze Negriego, np. Tripho wymieniający miasta w „mniszej” prowincji pochodzące od nazw zakonów przeinacza nazwę dominikanów: „Demonicana (Dominicana volui dicere)” (k. 20r), wcześniej zaś Fabius w rozmowie z Diaconatusem, zastanawiając się nad etymologią wyrazu „kardynał”, mającego na zasadzie epentezy pochodzić rzekomo od „,ielesności”, tłumaczy, czym jest ten zabieg językowy: ,ut quum induperatorem pro imperatorem proferimus, ita etiam cardinalem pro carnalem dictum volunt" [podkr. W.K.]

${ }^{23}$ F. Negri, Liberum, Pesclavii 1559, k. 23v-24r. Fragment przedrukowany w: A. Trzecieski, Carmina. Wiersze łacińskie, thum. i oprac. J. Krókowski, Wrocław 1958, s. 538-539. W przekładzie: „Nie mogę bowiem zostać doprowadzony [do tego], bym uwierzył, że zawiera błąd kodeks, który został mi przysłany w podarunku z biblioteki szlachetnego i cudownej wymowy pana Andrzeja Trzecieskiego, ponieważ ten szlachetny i pobożny młodzieniec, najbieglejszy w trzech językach, nie zniósłby ze spokojem, że jakikolwiek błąd plami jego książki. Nie mogę się powstrzymać, skoro wspominamy o tym znakomitym młodzieńcu, żeby nie odczytać ci tej ody, wprawdzie krótkiej, lecz wcale nie nieskładnej, przy pomocy której jeden jego przyjaciel zalecił go niegdyś prawdziwej sławie właśnie tymi słowy: «Są tacy, co zdobywają wyniosłe góry Parnasu, spokojne domy Pieryd, niech staną się sławni pośród śmiertelnych, których chwalą swoją pieśnią, lecz Trzecieski zmęczony sławą przodków i zarazem swoją własną, wzgardzający tymi próżnymi rzeczami, choć Pegaz chętny, by utrzymywać tego jeźdźca na swoim grzbiecie najwyższą cnotą, najlepszymi zwyczajami i trzema językami w równym stopniu ozdobiony, z powodu których jest też pobożność [jego] towarzyszką prosi niebo gwiaździste, niech chwali znaki [Boże] stosownymi pochwałami». A teraz ty, Tryfonie, mów dalej” (tłum. Martyna Osuch).

24 Zob. H. Łopaciński, Trzecieski Andrzej, w: Encyklopedia kościelna, t. 29, Warszawa 1907, s. 12 (tu mylnie Lukrecjusz zamiast Lukana); J. Krókowski, Andrzej Trzecieski. Poeta-humanista i działacz reformacyjny, Warszawa 1954, s. 24. 
(k. 7r). Chwalony za erudycję Trzecieski, „,vir trium linguarum”, został pretekstowo włączony do fabuły utworu, do czego wykorzystano wzmiankę o bliżej nieokreślonej książce, jaką miał posiadać fikcyjny bohater Bertucius.

Druga z modyfikacji to amplifikacja wypowiedzi Hermesa pod koniec trzeciej sceny aktu III. W tej części utworu wspomniany bohater relacjonuje Diaconatusowi i Felinusowi nowinki „niemieckich teologów". Ich treść przekazał mu niejaki Ecchius (chodzi tu niewątpliwie o Johannesa Ecka, katolickiego polemistę Lutra), któremu przyszło dyskutować z nieznanym z imienia prawnikiem (określanym jako „causidicus”). Ów jurysta podważać miał zasadność prymatu papieskiego, a także istnienia i funkcjonowania innych ,prowincji” i „miast” Królestwa Dobrych Uczynków: mszy, ceremonii czy zakonów. Przeważająca część kwestii Hermesa stanowi przytoczenie wypowiedzi prawnika, które komentują pozostali uczestnicy sceny. W końcu rozmowy Diaconatus podsumował wywody jurysty, stwierdzając, że podważa on wszystkie reguły działania królestwa, na co Hermes przytoczył ostatnią wypowiedź prawnika, w której ten podkreślał konieczność przestrzegania praw danych przez Boga, nie przez ludzi. W anonimowym wydaniu w tym miejscu przywołany został Rej jako inna osoba, która w swoich pismach stoi na tym samym co ów jurysta stanowisku:

Testatusque hic est insuper olim se Nicolai Reii, equitis Poloni, carmen egregium patria ipsius lingua diserte conscriptum perlegisse, quo quidem Is, qua ratione iusti apud Deum homines re ipsa fiant ob oculos elegantissime posuerit. Cuius etiam rei causa non inepto penitus epigrammate fuerit ab amico non vulgari donatus.

Epigramma vero ipsum a Causidico recitatum, si mihi non excidit, huiuscemodi plane extitit:

Reius eques, Virtus cui candida Regis Achatem

Esse sui tribuit,

Compellans patrio dulceis sermone Camoenas

Concinit ore pio

Iustitiam semel amissam, absumptamque salutem

Primi hominis vitio,

Humana non posse iterum virtute parari,

Nec prece, nec precio.

Sanguine sed Christi tantum, quem summus ab alto

Aethere Patris amor

Misit, ut id praestet. Reparataque munera soli

Conferat haec Fidei ${ }^{25}$.

Po przytoczeniu wiersza chwalącego polskiego poetę Hermes wraca do rozmowy z Diaconatusem według tekstu wydania genewskiego, odnosząc się jeszcze do wypowiedzi prawnika i kończąc rozmowę. Uzupełnienie tekstu o odniesienie do Reja, w którym wzmiankowano jego polską twórczość, traktował A. Brückner za dowód znajomości pisarstwa Reja w Szwajcarii, w tym jego trawestacji Mercatora, z którą można by utożsamić wzmiankowany przez bohatera tragedii Negriego wierszowany utwór (pieśn - „carmen”). Niestety nie można tego argumentu utrzymać w mocy ze względu na niejasne pochodzenie tej pochwały poety, „carmen egregium patria ipsius lingua diserte conscriptum” może zaś oznaczać tak Kupca, jak i inne religijne utwory Nagłowiczanina, które mają zalecać ludzkiej

${ }^{25}$ F. Negri, Liberum, Pesclavii 1559, k. 67r-v. W przekładzie: „Zaświadczył on [Jurysta - Causidicus] także, że przeglądał dawniej wspaniałą pieśń szlachcica polskiego Mikołaja Reja spisaną kunsztownie w jego ojczystym języku. W tej to pieśni wytwornie postawił on przed oczy, w jaki sposób ludzie zostali usprawiedliwieni przed Bogiem za sprawą samej tej rzeczy. Z tego powodu został on [Rej] obdarowany przez przyjaciela bardzo eleganckim łacińskim [dosł. nie pospolitym non vulgari] epigramatem. Epigramat ten wyrecytowany przez Jurystę [a Causidico], o ile mi nie umknął, brzmiał w ten sposób: «Szlachcic Rej, któremu nieskalana cnota przyznała, aby był Achatesem swojego króla, przemawiający w słodkiej mowie ojczystej, Muzy opiewa pobożnym głosem: raz utracona sprawiedliwość i zbawienie odebrane z powodu występku pierwszego człowieka, nie mogą zostać ponownie pozyskane ludzką cnotą, ani poprzez modlitwę, ani przez pieniądze, lecz wyłącznie przez krew Chrystusa, którego z wysokiego nieba największa miłość Ojca posłała, aby to okazał. I aby udzielił wierze tych odzyskanych darów ziemi»" (tłum. Martyna Osuch). 
uwadze „tylko wzgląd na Boga” (choć gdyby „ratio” potraktować jako wyraz użyty tu na oznaczenie „usprawiedliwienia”, to wówczas ze względu na rolę, jaką w Кupcu odgrywa nauka o usprawiedliwieniu, być może skojarzenie jest zasadne) ${ }^{26}$.

Sięgające za granicę wiadomości o Trzecieskim jako szczególnej postaci związanej z polską reformacją wydaja się bardziej prawdopodobne. Jak jednak pokazuje obszerne zestawienie rozmaitych opinii i sądów o Trzecieskim z lat 1545-1652, pochwały pisarza pojawiają się wyłącznie w drukach wydanych w państwie polsko-litewskim lub, już w XVII w., napisanych przez Polaków (m.in. Szymona Starowolskiego, Andrzeja Węgierskiego ${ }^{27}$. Z cudzoziemców - poza omawianym anonimowym wydaniem Negriego - jedynie Vergerio raz zwrócił się w dedykacji do Trzecieskiego, ale i to w druku królewieckim wydrukowanym przez Hansa Daubmanna w $1560 \mathrm{r}^{28}$ Nie powinno natomiast dziwić poniekąd wspólne wystąpienie Reja i Trzecieskiego, którzy jako jedyni reprezentanci polskich ruchów reformacyjnych zostali wcieleni do utworu Negriego. Młodszy od Reja Trzecieski figuruje jako autor jego krótkiej biografii (Żywot i sprawy poćciwego ślachcica polskiego Mikołaja Reja...), jest autorem kilku wierszowanych jego pochwał umieszczanych jako parateksty w zbiorach pisarza $\mathrm{z}$ Nagłowic, zapewne współpracował z nim także przy przekładzie Księgi Psalmów ${ }^{29}$. Pomysłodawcą wkomponowania ich obu do tekstu Negriego był więc zapewne ktoś, kto świadom był ich wzajemnych stosunków, a nadto - kto celowo chciał ich owymi wzmiankami wyróżnić.

\section{Drukarz anonimowego wydania z 1559 r.}

Wydanie Negriego z 1559 r. nie było sygnowane przez żadnego drukarza. W dotychczasowej literaturze stawiano co prawda pewne hipotezy na temat pochodzenia omawianej książki, jednak w toku kwerend przeprowadzonych na potrzeby niniejszego artykułu sformułowano odmienną od nich. Wśród typografów, których produkcja zostanie tu rozpatrzona, znajdują się: dziedzice Marka Szarfenberga, Daniel z Łęczycy, Jan Karcan i Łazarz Andrysowic.

Wyrażona bowiem w katalogu Biblioteki Jagiellońskiej hipoteza przypisująca anonimowy druk oficynie dziedziców Marka Szarfenberga może budzić wątpliwości, gdy weźmie się pod uwagę charakter tej oficyny. Po śmierci Marka (1545) typografię przejęli i prowadzili spadkobiercy: najpierw wdowa Agnieszka, a w latach 1549-1564 synowie Mikołaj i Stanisław. Jak zwracano uwagę, wydawali oni przeważnie popularne dzieła o neutralnym konfesyjnie charakterze lub pozostające $\mathrm{w}$ zgodzie $\mathrm{z}$ katolicką ortodoksją ${ }^{30}$. Warto odnotować szczególną rolę wydań przekładów biblijnych, Nowego Testamentu (1556) i całego Pisma Świętego (1561), drukowanych dla odbiorcy katolickiego, nawet mimo subtelnej polemiki Jana Leopolity ze stanowiskiem teologów soboru trydenckiego, takich jak Stanisław Hozjusz ${ }^{31}$. Jedynym znanym polemicznym dziełem protestanckim z tej oficyny pozostaje De Trinitate et mediatore Domino nostro Iesu Christo z 1562 r., w pierwszym rzędzie skierowane zresztą przeciw zuryskiemu reformatorowi Heinrichowi Bullingerowi, a nie teologom katolickim.

Anonimowy druk z 1559 r. nie zawiera zbyt wielu charakterystycznych elementów, co wydaje się naturalne w przypadku zamiaru ukrycia lub sfałszowania adresu wydawniczego. Ozdobniki typograficzne w kształcie liści bluszczu (hedera) umieszczone m.in. na pierwszej stronie dedykacji (Aneks 2, il. 3) pozostają, podobnie jak użyte czcionki, znakami na tyle podobnymi do produkcji innych oficyn, że bez

26 J.T. Maciuszko, Mikołaj Rej - zapomniany teolog ewangelicki z XVI w., Warszawa 2002, s. 263-270.

${ }^{27}$ Zob. odpowiednie fragmenty S. Starowolskiego Scriptorum Polonicorum Hecatontas (1627) i A. Węgierskiego Slavonia reformata (1679) przedrukowane w: A. Trzecieski, Carmina, s. 545-546.

28 Tamże, s. 535-546.

${ }^{29}$ Związki te podsumowuje np. J. Krzyżanowski, Rej i Trzecieski, w: Mikołaj Rej w czterechsetlecie śmierci, red. T. Bieńkowski i in., Wrocław 1971, s. 7-13.

${ }^{30}$ A. Kawecka-Gryczowa, A. Mańkowska, Szarfenberga Marka dziedzice, w: Drukarze dawnej Polski, t. 1: Małopolska, cz. 1: Wiek XV-XVI, red. A. Kawecka-Gryczowa, Wrocław 1983, s. 261-263.

31 Zob. więcej: D. Frick, Polska „philologia sacra” w czasach reformacji i kontrreformacji, thum. K. Szymańska, Warszawa 2018, s. 66-74. 
wiedzy o kontraktach poszczególnych giserów trudno byłoby orzekać z całą pewnością o drukarzu, gdyż jeden odlewacz, zwłaszcza wędrowny, niejednokrotnie obsługiwał więcej niż jedną oficynę ${ }^{32}$. W druku użyto tylko dwóch inicjałów drzeworytowych - „S” (k. a r r) i „L” (k. 1r) $)^{33}$. Jedynie one zwracają uwagę jako potencjalnie unikalne na tle prostego, pozbawionego ozdobników wyposażenia typograficznego i drzeworytowego anonimowego druku. Na podstawie analizy owych inicjałów, a także innych cech tego wydania (w szczególności zastosowanego pisma drukowanego oraz filigranów papieru drukowego użytego do wytłoczenia książki) wskazana zostanie najprawdopodobniejsza atrybucja.

\section{Inicjaly drzeworytowe}

W Centralnym Katalogu Poloników XVI wieku w Bibliotece Narodowej na fiszce rejestrującej egzemplarze Liberum Arbitrium zwrócono uwagę na dwie typograficzne zbieżności odnoszące się do owych ozdobnych inicjałów. Po pierwsze, wskazano na oficynę Jana Karcana. Działał on w Łosku od 1576 r., a w latach 1580-1611 w Wilnie i ze względu na późny w stosunku do wydania utworu czas jego aktywności jest raczej mało prawdopodobne, aby to on był odpowiedzialny za druk dzieła. Po drugie, odnotowano jeszcze obecność podobnych inicjałów w Drukarni Łazarzowej (działającej w Krakowie od 1558, w 1578 r. przejętej przez syna Łazarza, Jana Januszowskiego), której okres aktywności obejmuje także czas wydania omawianego anonimowego druku. Udało mi się ponadto zidentyfikować odbicia inicjałów z tych samych klocków drzeworytowych w drukach, które wyszły spod prasy drukarza pracującego dla zboru w Pińczowie, Daniela z Łęczycy. Typograf ten działał w Pińczowie na zlecenie miejscowego zboru, rozwijającego się pod patronatem właściciela miasteczka, Mikołaja Oleśnickiego. Zapewne rozpoczął tam pracę w 1557 r. (lecz pierwsze druki datowane są na $1558 \mathrm{r}$.). W okresie bezpośrednio poprzedzającym rozłam zboru, pod koniec 1562 r., przeniósł się Daniel do Nieświeża, w którym prowadził warsztat przez kolejną dekadę, później zaś osiedlał się w Zasławiu, Łosku i wreszcie w Wilnie, gdzie ślady jego aktywności prześledzić można do $1600 \mathrm{r}^{34}$

Spośród publikacji, które wyszły z pińczowskiej drukarni Danielowej, inicjał „S” odbity z tego samego klocka drzeworytowego co w anonimowym druku zawierającym Liberum Arbitrium odnaleźć można w dwóch drukach z 1559 r. sygnowanych przez typografa: polemicznym piśmie Jana Łaskiego Brevis ac compendiaria responsio... oraz przedruku przywiezionych przez Francesca Lismanina listów ministrów ewangelickich ze Szwajcarii, które ukazały się pod tytułem Exemplum literarum Ecclesiae Tigurinae ad Ecclesias Polonicas ${ }^{35}$. Nie udało się jednak ustalić żadnych innych odbić z tego samego klocka z inicjałem „L”.

O ile w piśmie polemicznym Łaskiego użyto tylko jednego inicjału, o tyle w Exemplum literarum odnaleźć można także inne przykłady ozdobnych liter, które pochodzą najpewniej z tego samego zestawu klocków drzeworytowych o rozmiarach ok. 2,6 x 2,6 cm: „E” oraz „Q”,36. Kwerenda przeprowadzona na potrzeby niniejszego badania pozwoliła ustalić wystąpienia dwunastu ozdobników literowych o zbliżonych wymiarach (z wahaniami do $1 \mathrm{~mm}$ ) oraz zbliżonych cechach stylistycznych (konturowe kapitaliki bez wypełnienia na tle z przeważnie symetrycznie zakomponowanych prostych floratur). Skłania to do spojrzenia na problem atrybucji z perspektywy nie tylko odbić z dwóch klocków występujących w druku z fałszywym adresem „Pesclavii”, lecz także uwzględnienia ciągłości użytkowania kompletu ozdobnych liter pochodzących z zestawu spójnego pod względem rozmiaru i stylistyki. Daniel z Łęczycy wykorzystywał inicjały pochodzące z tego kompletu przez cały czas swojej aktywności: od najwcześniejszych

\footnotetext{
32 A. Tomaszewski, Giserzy czcionek w Polsce. Poczet odlewaczy czcionek działajacych w dawnej Polsce oraz polskich za granica, Warszawa 2009, s. 14-15.

${ }^{33}$ Zob. W. Kordyzon, Zasób drukarski Daniela z Łęczycy (1530-1600), <https://doi.org/10.18150/VEKCVF> [dostęp: 20.05.2021], nr I.13 i I.7.

${ }_{34}$ A. Kawecka-Gryczowa, Daniel z Łęczycy, w: Drukarze dawnej Polski od XV do XVIII wieku, z. 5: Wielkie Księstwo Litewskie, red. A. Kawecka-Gryczowa, Wrocław 1959, s. 70-86.

${ }^{35}$ Zob. W. Kordyzon, Zasób, nr I.13.

${ }^{36}$ Zob. tamże, nr I.4 i I.12.
} 
druków pińczowskich aż po okres wileński. Klocki te odbijał przede wszystkim w drukach łacińskich, do tekstów polskich rezerwując inny zestaw czcionek o kroju niemieckim (odnotowanymi wyjątkami są dwa późne pisma polskojęzyczne z $1592 \mathrm{r}^{37}$ ).

Należy także zauważyć, że wśród zarejestrowanych odbić znalazły się dwa jeszcze - poza samym dziełem Negriego - inne druki pozbawione adresów wydawniczych, oba pochodzące z okresu, gdy Daniel działał w Pińczowie. Anonimową rozprawę De primatu papae z 1558 r. przypisał Andrzejowi Fryczowi Modrzewskiemu Stanisław Kot. Uczony wskazał, że prawdopodobnym miejscem druku był Brześć Litewski, poszedł bowiem za atrybucją innego anonimowego druku dokonaną przez Kazimierza Piekarskiego, a na kartach obu druków użyto tej samej winiety ${ }^{38}$. W literaturze druk funkcjonował potem jednak jako pińczowski, co wydaje się słuszniejsze ${ }^{39}$. Hipotezę tę potwierdza fakt, że ozdabiające druk inicjały „E” i „Q” odbite zostały z tego samego klocka także w innych drukach Daniela z Łęczycy, w większości sygnowanych nazwiskiem typografa, w Pińczowie oraz w Wilnie ${ }^{40}$. Drugie pismo pozbawione adresu wydawniczego (a ponadto i roku wydania), to jednoskładkowy przedruk antyariańskiego dziełka Arriana haeresis... przypisywanego św. Augustynowi. Znajduje się tam odbicie z klocka ze wspominanym już inicjałem „Q", a także „A" ${ }^{\text {41 }}$, który wytłoczony został z tego samego klocka, co ozdobnik w trzy lata późniejszym dziele Narratio simplex... pióra Modrzewskiego. Na warsztatową proweniencję drugiego z anonimowych druków wskazała Alodia Kawecka-Gryczowa ${ }^{42}$.

W zbadanych drukach Jana Karcana odnaleziono dwa wystąpienia inicjału „S"43 podobnego do tego użytego w anonimowym druku z 1559 r. oraz innych ozdobnych liter z odpowiadającego im stylistycznie zestawu, którego używał wileński impresor w drukach pochodzących z lat 80. XVI w. (1584-1588) oraz początku XVII w. ${ }^{44}$ Odnotowane odbicia cechuje wyraźnie niższa jakość niż w Liberum Arbitrium z 1559 r. oraz w sygnowanych drukach Daniela z Łęczycy: są krzywe, a farba drukarska rozprowadzona nierównomiernie. Można przypuszczać, że niedostatki spowodowane zostały nie tylko błędami w procesie druku, np. wadliwym naciskiem prasy, lecz wynikają także z samego opracowania klocków, gdyż druki Karcana uchodzą ogólnie raczej za staranne. Porównanie szczegółów odbitek tych samych inicjałów w drukach sygnowanych z osobna przez dwu wskazanych drukarzy (Aneks 3, tab. 1a-b) potwierdza, że inicjały Karcana są najpewniej, przynajmniej w części, kopiami zrobionymi z zestawu posiadanego przez Daniela z Łęczycy. Inicjały w drukach tłoczonych przez Karcana różnią się detalami w opracowaniu listowia (wskazane w tabeli strzałkami okrągłe dodatki - niewykluczone, że naniesione na kopie celowo, by odróżnić jeden zestaw od drugiego). Ponieważ różnice te występują konsekwentnie

37 Zob. tamże, nr I.8 i I.11.

${ }^{38}$ S. Kot, Opposition to the Pope by the Polish Bishops, 1557-1560, „Oxford Slavonic Papers”, 4, 1953, s. 42, 47. Zob. także polemikę z tą atrybucją autorską (jednak bez odniesień do potencjalnego miejsca wydania czy drukarza): Ł. Kurdybacha, Zagadnienie autorstwa traktatu „De primatu papae”, „Odrodzenie i Reformacja w Polsce”, 4, 1959, s. 81-86.

39 A. Kawecka-Gryczowa, Pińczów, w: Drukarze dawnej Polski, t. 1, cz. 1, s. 141.

${ }^{40}$ Zob. W. Kordyzon, Zasób, nr I.4 i I.12.

41 Zob. tamże, nr I.1.

${ }^{42}$ A. Kawecka-Gryczowa, Pińczów, s. 142.

${ }^{43}$ Odbicia te znajdują się w drukach: 1) A. Wolan, Idolatriae Loiolitarum Vilnensum oppugnatio, Vilnae 1583, k. A $\mathrm{r}$ (egz. BKórn., sygn. Cim.Qu.2596); 2) P. Lilia, Responsio ad cuiusdam Nicolai Regii Germani epistolam..., Vilnae 1584, k. A r (egz. BN, sygn. SD XVI.Qu.1581).

${ }^{44}$ Odbić inicjałów z zestawu Karcana - ponieważ stanowią kopie materiału Daniela z Łęczycy - nie odnotowano. Użycia inicjałów z tego zestawu zanotowano w następujących drukach: 1) A. Wolan, Idolatriae Loiolitarum Vilnensum oppugnatio, Vilnae 1583; 2) P. Lilia, Responsio ad cuiusdam Nicolai Regii Germani epistolam..., Vilnae 1584; 3) S. Simonius, Commentariola medica et physica..., Vilnae 1584; 4) A. Possevino, Atheismi Lutheri $[\ldots .$.$] et aliorum nostri temporis heareticorum$ duo item libri refutati, Vilnae 1586; 5) tenże, Societati Iesu Moscovia, Vilnae 1586; 6) A. Jurgiewicz, Mendacia et convitia evangelica Andreae Volani Lwowkoviensis, Vilnae 1588; 7) J. Radvanas, Radivilias sive de vita et rebus praeclarissime gestis Nicolai Radivili, Vilnae 1588; 8) S. Kiszka, In auspicatum illustrissimi ac reverendissimi Benedicti Wojnae gratulatio, Vilnae 1600; 9) A. Rochmanius, Assertiones ex universa [...] theologia desumptae, Vilnae 1602; 10) Equitis Lituani de bello Livonico per decennium gesto, Vilnae 1610. Na temat zasobu typograficznego Karcana zob. F. Rozen, Problem drukarza książki „O jednej osobie” Stanisława Grodzickiego, „Czasopismo Zakładu Narodowego im. Ossolińskich”, 28, 2018, s. 183-197 (tamże, s. 197, przedrukowany inicjał „I” z tego zestawu; autor nie wskazywał jednak na powiązanie tego elementu z materiałem typograficznym Łęczycanina). 
w odbiciach sygnowanych przez Karcana, a nie ma ich w drukach oficyny Danielowej, należy sądzić, że świadczą o własnościach klocków i równoległym funkcjonowaniu odrębnych zestawów. Okazja do skopiowania pojawiła się najpewniej w Wilnie, gdzie Łęczycanin pracował od 1576 r. dla Drukarni Radziwiłłowskiej, a od 1581 r. dla oficyny zboru ewangelickiego ${ }^{45}$. Z kolei Karcan sprowadził się do Wilna w 1580 r., przez pierwsze trzy lata również współpracując z tutejszym zborem (ale wzrost jego produkcji zauważyć można dopiero w 1584 r., gdy począł przyjmować coraz liczniejsze zamówienia pisarzy i polemistów katolickich) ${ }^{46}$. Sądzić można, że do wycięcia zestawu Karcana doszło właśnie na początku lat 80., gdy obaj drukarze pracowali dla wileńskich ewangelików, na pewno nie później jednak niż w 1583 r., gdy - przypuszczalnie po raz pierwszy - kopie inicjałów Danielowych użyte zostały do ozdobienia antyjezuickiego Idolatriae Andrzeja Wolana. Rozpoznawszy odmienność inicjałów używanych przez Karcana od tych występujących w anonimowym Liberum Arbitrium i mając na względzie okres jego działalności, $\mathrm{z}$ dużą dozą pewności wykluczyć można tego typografa $\mathrm{z}$ kręgu potencjalnych impresorów odpowiedzialnych za wydanie druku „Pesclavii” 1559.

Po jednym odbiciu liter „S” i „L” podobnych do inicjałów znanych Liberum Arbitrium z 1559 r. odnaleziono także w książkach pochodzących z Drukarni Łazarzowej ${ }^{47}$. Także w innych drukach tej krakowskiej typografii odnaleźć można odciski innych liter ze spójnego rozmiarowo i stylistycznie zestawu klocków drzeworytowych (tak w publikacjach sygnowanych przez Łazarza Andrysowica, jak i w książkach wydanych po jego śmierci w 1577 r., podpisywanych ,in officina Lazariana” przez spadkobiercę, Jana Januszowskiego $)^{48}$. Z kilku względów sądzić można jednak, że to pińczowska drukarnia pozostaje bardziej prawdopodobnym miejscem wydania tragedii Negriego, a Łazarz i Januszowski posługiwali się równolegle innym zestawem klocków niż Daniel z Łęczycy (a nie że doszło przykładowo do wymiany zestawu klocków pomiędzy typografami). Oba zestawy zostały najpewniej wycięte w tym samym stylu przez tego samego rzemieślnika, przypuszczalnie krakowskiego (co zachęcałoby przy okazji do dalszego ugruntowania przypuszczeń Henryka Barycza, że to w stolicy Łęczycanin zapoznał się ze swoim fachem $^{49}$, a przynajmniej stamtąd pochodziła jakaś część wyposażenia jego warsztatu). Po pierwsze, chociaż w perspektywie obszernej produkcji Drukarni Łazarzowej odnotowane przykłady użyć klocków z omawianego zestawu są dość nieliczne, to świadczą o potencjalnej ciągłości: odbicia jednolitych stylistycznie inicjałów (choć nie tych samych) znajdują się tak w druku Łazarza z $1559 \mathrm{r}^{50}$, jak i we wczesnych drukach jego syna (1578 i $\left.1583^{51}\right)$, a zatem można podejrzewać, że zestaw dostępny był w zasobie oficyny przez cały ten czas. Po drugie, można wskazać drobne różnice pomiędzy odpowiadającymi sobie literami w zestawach obu oficyn drukarskich, które - ponieważ pojawiają się w więcej niż jednym odcisku - świadczą o odmienności klocków, a nie incydentalnie wadliwym procesie druku. I tak przykładowo inicjał „S” w zestawie Daniela z Łęczycy (Aneks 3, tab. 2a) zarówno w każdym zarejestrowanym odbiciu pińczowskim, jak i w anonimowym druku z 1559 r. ma drobne, słabo uchwytne na reprodukcji uszkodzenia u dołu wewnętrznych linii ramki: dwie po lewej i jedną z prawej (oznaczone $\mathrm{w}$ aneksie strzałkami). Inicjał Łazarza jest w tych miejscach nienaruszony. Wyraźniejsze w reprodukcji różnice zaobserwować można w inicjałach „Q” obu typografów, przekonujące o równoległym istnieniu bliźniaczych kompletów. W obu odnotowanych odbiciach klocka u Łazarza Andrysowica spostrzec można (Aneks 3, tab. 2b), że pomiędzy liniami ramki blisko górnego prawego rogu znajduje się nieduża kropka (jej powtarzalność może świadczyć, że to właściwość klocka) oraz nieduży ubytek

45 A. Kawecka-Gryczowa, Daniel z Łęczycy, s. 80-81.

${ }^{46}$ Taż, Karcan Jan, w: Drukarze dawnej Polski, z. 5, s. 111-112.

${ }^{47}$ Odbicia te znajdują się w drukach: inicjał „S”: I. Sambucus, Sententiae et regulae viate ex Gregorii Nazianzeni..., Cracoviae 1578, k. A 2 (egz. BN, sygn. SD XVI.Qu.16); inicjał „L”- S. Simonius, Historia aegritudinis ac mortis [...] domini a Niemsta ..., Cracoviae 1583, k. A rr (egz. BN, sygn. SD XVI.Qu.6444).

48 Wszystkie wystąpienia inicjałów z omawianego zestawu w drukach tej krakowskiej oficyny oznaczono pojedynczym asteryskiem (*) w przytaczanym zestawieniu klocków; zob. W. Kordyzon, Zasób, nr I.1-2, I.4-13.

49 H. Barycz, Daniel z Łęczycy, w: PSB, t. 4, Kraków 1938, s. 405.

${ }^{50}$ Zob. W. Kordyzon, Zasób, nr I.1-2, I.4-6, I.8-12.

51 Zob. tamże, nr I.7 i I.13. 
w zewnętrznej krawędzi w pobliżu prawego dolnego rogu. Po trzecie wreszcie, Łazarz bardzo rzadko drukował pisma autorów protestanckich. Wiadomo o serii druków ulotnych z pieśniami różnowierczymi z 1556 r. i kancjonale Bartłomieja Groickiego z 1559 r. ${ }^{52}$ Ponadto wydał jeszcze - nieznany dzisiaj z żadnego egzemplarza - podręcznik Louisa Enocha Partitiones grammaticae, który zalecany był przez Statoriusa trzecim klasom, wydany nieco wcześniej w Krakowie (między końcem 1557 a początkiem 1558 r. $)^{53}$. Z tego próbowano wysuwać wniosek o związku między gimnazjum pińczowskim a oficyną Łazarza przed zainstalowaniem drukarni Danielowej, choć nie ma chyba podstaw, by traktować ten podręcznik do greki - wprawdzie pierwotnie wydany przez Crespina w Genewie - jako konfesyjnie nacechowany ${ }^{54}$. Nieznane są poza tym - jawne czy zanonimizowane - pisma polemiczne skierowane przeciw katolikom, za których druk odpowiadałby Łazarz, a tragedia Negriego stanowi bardzo bezpośredni i niedwuznaczny atak na Rzym i papiestwo. W obliczu wskazanych przesłanek nie można całkowicie wykluczyć Łazarza z kręgu ,podejrzanych”, jednak to Daniel z Łęczycy jawi się jako typograf z większym prawdopodobieństwem odpowiedzialny za wytłoczenie Liberum Arbitrium.

\section{Pismo drukowane}

Dodatkowych argumentów atrybucyjnych dostarcza analiza pisma drukowanego. W niniejszym badaniu rozpatrzono pismo użyte do złożenia tekstu głównego. W wydaniu sine nomine z $1559 \mathrm{r}$. wykorzystane zostały czcionki kroju antykwowego o wysokości ok. $3 \mathrm{~mm}$ od linii bazowej do środkowej linii pisma (w Aneksie 4.1 zestawiono przykłady z zastosowaniem majuskułowej litery „Q” o wysokości ok. $4 \mathrm{~mm}^{55}$; por. także wygląd strony w Aneksie 2, il. 3). Zestawienie próbek pochodzących $\mathrm{z}$ anonimowego wydania $\mathrm{z}$ odpowiadającym pod względem kroju i wysokości zasobem typograficznym użytym do wytłoczenia druków sygnowanych przez Daniela z Łęczycy (Aneks 4.2) wskazuje, że pińczowski drukarz używał podobnych czcionek. Szczególnie zwraca uwagę zastosowanie takich czcionek majuskułowego „Q”, którego wstęga bądź to nie przekracza granicy szerokości następującej minuskułowej litery „u”, bądź też sięga jednej trzeciej jej szerokości. Litery tłoczone z czcionek o analogicznym kroju i wysokości występujące w sygnowanych drukach Łazarza Andrysowica wydanych ok. 1559 r. są wyraźnie odmienne ${ }^{56}$ : wstęga majuskułowego „Q” obejmuje całą szerokość następującej litery „u”. Nieco bardziej podobne pod względem szerokości do tych zastosowanych w wydaniu sine nomine z 1559 r. są czcionki używane w Drukarni Łazarzowej nieco wcześniej (wystąpienie z $1551 \mathrm{r}^{57}$ ), jednak należy zwrócić uwagę na odmienne ukształtowanie zakończenia tejże wstęgi: położone jest bliżej dolnego łuku litery „u”, pozostawiając mniej światła niż w wypadku liter wydania anonimowego. Różnice zbliżonej natury zaobserwować można przy porównaniu czcionek z Liberum Arbitrium z tymi używanymi w oficynie dziedziców Szarfenberga ${ }^{58}$ : albo występują w ich drukach majuskuły „Q”, których wstęgi obejmują całą szerokość następującej „u”, albo - w wypadku wstęg sięgających jednej trzeciej szerokości litery po prawej - wstęgi te mają inne zakończenia skierowane, ostrzejsze i skierowane bardziej ku dołowi.

52 A. Kawecka-Gryczowa, A. Mańkowska, Lazarz Andrysowic, w: Drukarze dawnej Polski, t. 1, cz. 1, s. 126-127. Kancjonał Groickiego, znany przed wojna jedynie z egzemplarza zgorzałej biblioteki dzikowskiej, ze względu na brak zachowanych kopii nie może być już poddany oglądowi. Wydany został jednak sine nomine, a Drukarni Łazarzowej przypisany. Choć jest to wysoce prawdopodobne, Łazarz bowiem drukował także inne teksty Groickiego (zwłaszcza prawnicze), niestety nie daje się dzisiaj tego zweryfikować.

53 S. Kot, Pierwsza szkoła protestancka w Polsce. Z historii wptywów francuskich na kulturę polska, w: tenże, Polska złotego wieku a Europa. Studia i szkice, oprac. H. Barycz, Warszawa 1987, s. 269.

${ }^{54}$ Por. A. Kawecka-Gryczowa, A. Mańkowska, Lazarz Andrysowic, s. 127; zob. też O. Reverdin, Homère chez Calvin. Figures de l'hellénisme à Genève, Genéve 2000, s. 41.

55 Przyjmuje się, że „Q” jest literą charakterystyczną krojów antykwowych; zob. H. Bułhak, Metoda typograficzna w badaniach nad dawna ksiażka. Uwagi i refleksje, „Biuletyn Poligraficzny”, 10, 1977, nr 2, s. 41.

${ }_{56}$ Zob. W. Kordyzon, Zasób, nr III.3, A-B.

${ }^{57}$ Zob. tamże, nr III.3, C.

58 Zob. tamże, nr III.4. 
Ponadto warto wskazać, że wspomniany na początku, pozornie charakterystyczny odcisk liścia bluszczu (hedera) użyty kilkakrotnie w anonimowym wydaniu z 1559 r. (Aneks 2, il. 3), pojawiał się wprawdzie w sygnowanych drukach Daniela z Łęczycy, m.in. w Brevis ac compendiara Łaskiego z tego samego roku (Aneks 2, il. 4), a także Statoriusa In duos Martini Cromeri dialogos ${ }^{59}$. Zarazem jednak znak ten w zbliżonych wymiarach występuje tak w oficynie dziedziców Szarfenberga ${ }^{60}$, jak i innych drukach typografii krakowskich tego czasu, których ze względu na brak jakichkolwiek dodatkowych przesłanek nie można uznać za prawdopodobnych wydawców ${ }^{61}$. Należy sądzić, że znak ów jest niespecyficzny. Jego obecność w drukach różnych oficyn nie ma więc charakteru rozstrzygającego, choć zarazem nie wyklucza ani oficyny Danielowej, ani innych rozważanych atrybucji.

\section{Filigrany papieru drukowego}

Osobno pozostaje omówić jeszcze zagadnienie atrybucji dokonanej w Bibliotece Jagiellońskiej. Gromadząc materiały do niniejszego artykułu, nie odnalazłem w drukach Marka Szarfenberga ani jego dziedziców żadnych odbić z tych samych lub podobnych klocków, co użyte w anonimowym druku z 1559 r. (choć nie można oczywiście wykluczyć, że znał je autor hasła w katalogu BJ). Istnieje jednak i inne możliwe wythumaczenie atrybucji z BJ. Mowa mianowicie o analizie papieru. Liberum Arbitrium wydrukowana została na papierze $\mathrm{z}$ występującymi naprzemiennie dwoma typami przedstawień $\mathrm{w}$ filigranach $^{62}$. Oba wskazują na papiernie podkrakowskie związane z rodziną Szarfenbergów, co mogło doprowadzić do hipotezy o krakowskiej proweniencji druku. Pierwszy z nich stanowi wariant herbu Kozioł (w tarczy herbowej pozbawionej korony), którym posługiwali się nobilitowani Szarfenbergowie w latach ok. 1557-1583 ${ }^{63}$. Jadwiga Siniarska-Czaplicka za Włodzimierzem Budką stwierdziła, że choć owa rodzina drukarska posiadała aż trzy podkrakowskie papiernie, to emblemat ten był stosowany zapewne tylko w manufakturze w Balicach. Zauważyła także, że zakres występowania papierów z tym znakiem wodnym ,jest dość szeroki” ${ }^{4}$. Drugim filigranem pojawiającym się w wydaniu Negriego jest konwencjonalna podwójna lilia w tarczy herbowej, która najbardziej przypomina herb Bonarowa ${ }^{65}$, używany do znakowania papierów w tej samej papierni balickiej (ok. 1522-1572), najpierw przez pierwotnych właścicieli, czyli uszlachconych mieszczan Bonerów, a potem także przez kolejnych właścicieli manufaktury, czyli Szarfenbergów ${ }^{66}$.

Podczas poszukiwań przeprowadzonych w egzemplarzach druków Daniela z Łęczycy z okresu pińczowskiego ${ }^{67}$ nie udało mi się odszukać żadnego, w którym występowałby filigran z herbem Kozioł. Odnalazłem jednak papiery z dwoma odmianami znaku wodnego opartego na herbie Bonarowa. Oba wykorzystane

59 P. Statorius, In duos Martini Cromeri dialogos, qui de vera et falsa nostri temporis religion inscribuntur animadversiones brevissimae, Pinczoviae: Daniel z Łęczycy, 1560, k. A.r. (egz. Wojewódzkiej Biblioteki Publicznej - Książnicy Kopernikańskiej w Toruniu, sygn. L. $8^{\circ} 169$ adl.2).

${ }^{60}$ Zob. np. R. Lorich, Księgi o wychowaniu i o ćwiczeniu każdego przełożonego, tłum. S. Koszutski, Kraków: dziedzice Marka Szarfenberga, 1558, k. a ${ }_{4}$, $\mathrm{a}_{5} \mathrm{v}$ (egz. BOss., sygn. XVI.F.4052); T. Piotrkowczyk, De comoetae anno Christi 1558, Cracoviae: dziedzice Marka Szarfenberga, 1558, k. D r (egz. BN, sygn. SD XVI.O.56).

${ }^{61}$ Zob. J. Górski, De periodis atque numeris oratoriis libri duo, Cracoviae: Mateusz Siebeneicher, 1558, k. G $\mathrm{r}$ (egz. BN, sygn. SD XVI.O.444 adl.).

${ }^{62}$ Pod kątem pochodzenia papieru analizowałem egzemplarz BUWr., sygn. 401049; por. przyp. 3.

${ }_{63}$ Zob. W. Kordyzon, Zasób, nr II.1a-b.

${ }^{64}$ J. Siniarska-Czaplicka, Filigrany papierni położonych na obszarze Rzeczypospolitej Polskiej od początku XVI do XVIII wieku, Wrocław 1959, s. 11. Wzór filigranu przypomina najbardziej pozycję nr 455, tabl. LXXXIII; zob. też J. Ptaśnik, Papiernie w Polsce XVI wieku, oprac. i uzup. W. Budka, Wrocław 1971, s. 19-20; W. Budka, Znaki wodne papierni Rzeczypospolitej Polskiej XVI wieku, w: tamże, nr 23-25.

${ }^{65}$ Zob. W. Kordyzon, Zasób, nr II.2a-b.

${ }^{66}$ J. Siniarska-Czaplicka, Filigrany, s. 7. Wzór filigranu przypomina najbardziej pozycję nr 44 (znany z rkps. datowanego na 1564), w mniejszym stopniu nr 43 (rkps datowany na 1562), tabl. VIII.

${ }^{67}$ Przeanalizowano druki pochodzące z oficyny pińczowskiej z lat 1558-1562, a także - kontrolnie - późniejsze publikacje Daniela z Łęczycy przechowywane w: BN, Bibliotece Uniwersyteckiej w Warszawie, BUWr., BKórn., BOss. 
zostały we wspomnianym już druku Exemplum literarum z 1559 r. ${ }^{68}$ Pierwszy z nich pozostaje najbliżej odmian filigranów balickich odnotowanych w zestawieniu W. Budki ${ }^{69}$. Choć nie odpowiada całkowicie żadnemu, sądzić można, że prawdopodobnie i ten znak wodny oznacza papier wytworzony w tamtejszej manufakturze ze względu na podobieństwo podwójnej lilii przepasanej pierścieniem i umieszczonej w tarczy herbowej. Drugi natomiast wygląda na tożsamy z filigranem występującym w wydaniu Negriego ${ }^{70}$ : w obu przypadkach płatki lilii u nasady, wychodzące spod kulisto przedstawionego pierścienia, zostały wyciśnięte z blisko ułożonych drucików, dając efekt bliższy plamie i utrudniając wskazanie wyraźnych konturów w tym miejscu. Z dużą pewnością można zatem stwierdzić, że przynajmniej częściowo papiery użyte w obu drukach z 1559 r. pochodzą z tej samej partii, najpewniej otrzymanej z Balic. Daniel z Łęczycy, jak wykazał wstępny ogląd jego pińczowskich druków, często mieszał papiery z różnymi znakami wodnymi, niekoniecznie wskazującymi na jednolite pochodzenie. Nie wydaje się to zresztą szczególnym odstępstwem od praktyk zaobserwowanych u innych drukarzy, którzy unikali stosowania papieru mieszanego głównie przy wydawnictwach luksusowych ${ }^{71}$. W wypadku typografa pińczowskiego jest to tym bardziej prawdopodobne, że utrzymywany był przez lokalny zbór o ograniczonych zasobach finansowych, a zatem trudniej byłoby mu pozwolić sobie na stałe, obszerne dostawy z jednego źródła. Mimo to posługiwał się raczej papierem dobrej jakości, pochodzącym przeważnie z czerpalni krakowskich ${ }^{72}$.

\section{Wnioski}

Podsumowując, rozpoznanie balickiej proweniencji papierów użytych do druku Liberum Arbitrium mogło zaważyć na atrybucji druku sine nomine dziedzicom Szarfenberga w katalogu BJ, nie jest wszakże zwłaszcza w obliczu przedstawionych argumentów dotyczących użytego zasobu typograficznego - przesądzające. Zastosowany w anonimowym wydaniu papier mógł być użyty przez Daniela z Łęczycy, na co wskazują występujące w sygnowanych przezeń publikacjach filigrany z Balic, a ponadto jego pismo drukowane i przede wszystkim zastosowane inicjały drzeworytowe w największym stopniu odpowiadają materiałowi występującemu w druku Liberum Arbitrium. Oficynę Jana Karcana należy wykluczyć tak ze względu na okres jej działalności, jak i istotne różnice pomiędzy używanymi przez niego klockami drzeworytowymi a wydaniem sine nomine, które stanowily zapewne komplet skopiowany od Daniela z Łęczycy. Zasób typograficzny Drukarni Łazarzowej jest zaś wyraźnie odmienny, choć stosowane w oficynie inicjałowe klocki drzeworytowe stanowiły, jak można sądzić, zestaw bliźniaczy wobec Danielowego, aczkolwiek różniący się na tyle, by mówić o równoległym funkcjonowaniu dwóch kompletów. $\mathrm{Z}$ tego względu sądzić można, że przypisanie anonimowego wydania z 1559 r. pińczowskiej oficynie Daniela z Łęczycy jest najbardziej prawdopodobne w świetle przedstawionych argumentów. Dowodzi tego zwłaszcza funkcjonowanie zestawu inicjałów, podczas gdy analiza pisma drukowanego i znaków wodnych pozwoliła się upewnić, że nie ma w tej hipotezie sprzeczności.

\section{Pińczowski program wydawniczy i możliwe cele przyświecające wydaniu Negriego}

Zmiana atrybucji tego anonimowego druku ma swoje konsekwencje dla postrzegania programu wydawniczego realizowanego w Pińczowie. Decyzje samego Daniela z Łęczycy, zatrudnionego przez zbór ewangelicki, wykraczały - przynajmniej w niektórych wypadkach - poza zlecenia stamtąd przyjmowane.

${ }^{68}$ Analizowałem egzemplarz BN, sygn. SD XVI.O.92; zob. W. Kordyzon, Zasób, nr II.3-4.

${ }^{69}$ W. Budka, Znaki wodne, nr 16-20.

${ }^{70}$ Zob. W. Kordyzon, Zasób, nr II.3.

${ }^{71}$ J. Siniarska-Czaplicka, Papier drukowy źródtem badań księgoznawczych, w: Dawna ksiązka i kultura. Materiały międzynarodowej sesji naukowej z okazji pięćsetlecia sztuki drukarskiej w Polsce, red. S. Grzeszczuk, A. Kawecka-Gryczowa, Wrocław 1975, s. 137-139.

72 Taż, Papier druków tloczonych na ziemiach województw krakowskiego i sandomierskiego w latach 1550-1700, Kwart. HKM, 14, 1976, nr 2, s. 256, 262. 
Stało się to przedmiotem sporu między typografem a małopolskimi ministrami, co świadczy o tym, że poważnie oczekiwano od niego lojalności w realizacji określonego programu, zgodnego z wizją przełożonych $^{73}$. Na synodzie włodzisławskim w czerwcu 1559 r. oskarżono Daniela o rozpowszechnianie niechcianych przez zbór pism. Akta synodalne wyraźnie wskazują na liczbę mnogą, choć z całą pewnością wiadomo tylko, że należały do owych potępionych dzieł wydane w 1558 r. pisma Francesca Stancara (Collatio doctrinae Arii et Philippi Melanchthonis...), których nakład został przypuszczalnie spalony ${ }^{74}$. Drukarz thumaczył się wówczas presją wywieraną nań przez jednego z członków wspólnoty, rzekomo powołującego się na patrona zgromadzenia, Oleśnickiego. Nie jest natomiast jasne, dlaczego A. Kawecka-Gryczowa zaliczyła w poczet zganionych we Włodzisławiu pism także wydaną anonimowo Arriana haeresis św. Augustyna uzupełnioną o tzw. symbol atanazjański, podkreślający ortodoksyjną naukę o Trójcy Świętej, podzielaną przecież przez ówczesne władze zborowe, odżegnujące się od koncepcji antytrynitarskich ${ }^{75}$. Być może słuszniej byłoby widzieć to pismo jako próbę zwalczenia frakcji wczesnoantytrynitarskiej czy trydeistycznej, zalążkowo wówczas formującej się w zgromadzeniu małopolskim ${ }^{76}$.

Taka niesubordynacja (choć o nieznanym zakresie) mogła wynikać z niewielkich korzyści majątkowych, jakie przynosiła Danielowi działalność w Pińczowie. Pod koniec 1559 r. zagroził wręcz opuszczeniem swoich mocodawców, którzy w kolejnym roku poczęli solennie obiecywać poprawę warunków bytowych i finansowych. Skutki ich działań okazały się ostatecznie niesatysfakcjonujące, ale wystarczyły, by zatrzymać drukarza na jeszcze dwa i pół roku ${ }^{77}$. Całość produkcji Daniela w Pińczowie z lat ok. 1558-1562 szacowana jest na ok. 25 pozycji; nawet przy założeniu, że liczbę tę należałoby powiększyć o niezachowane czy hipotetyczne niezidentyfikowane publikacje świadczy to o niewielkiej skali działalności wydawniczej.

Można się zastanowić, czy dałoby się wobec tego wskazać kogoś, kto odpowiadał za wybory wydawnicze w pińczowskiej drukarni. Wydaje się, że spośród wielu znamienitych działaczy reformacyjnych z największą liczbą publikacji pochodzących ze zborowej oficyny powiązany jest Francesco Lismanino. Ten były franciszkanin zajmował jedną z kluczowych pozycji w hierarchii małopolskiego zboru $^{78}$. Prawdopodobnie to on odpowiadał za organizację akcji wydawniczej przeciwko Stancarowi w 1559 r. W drukarni Danielowej ukazały się wówczas co najmniej trzy pisma mające wspomóc ministrów w zwalczaniu koncepcji Stancara: Confessio de mediatore generis humani Iesu Christo Deo et homine Caspara Helta, Responsio de controversiis Stancari Filipa Melanchtona i wspomniane już Exemplum literarum. Wstęp przygotowany przez Lismanina poprzedza także polski przekład Trajedyi o Mszej Bernardina Ochina, który wydrukowano w 1560 r. O zaangażowaniu w działalność wydawniczą i świadomości jej oddziaływania poza kręgiem wewnątrzzborowym świadczą także informacje, że odpowiadał za rozsyłanie egzemplarzy mowy okolicznościowej po śmierci Jana Łaskiego w 1560 r. ${ }^{79}$

Gdyby więc typować osobę, która za wydanie Negriego mogła być w Pińczowie odpowiedzialna, Lismanino wydaje się najtrafniejszym wyborem. To on poinformował Szwajcarów o pobycie Negriego w Polsce w 1563 r. ${ }^{80}$ Wykorzystał ponadto jeszcze jeden jego utwór w 1565 r., już po śmierci Bassańczyka,

73 A. Kawecka-Gryczowa, Daniel z Łęczycy, s. 73.

74 P. Buchwald-Pelcowa, Cenzura w dawnej Polsce. Między prasa drukarska a stosem, Warszawa 1997, s. 176; H. Kowalska, Działalność reformatorska Jana Łaskiego w Polsce 1556-1560, Warszawa 1999, s. 142-144.

75 A. Kawecka-Gryczowa, Pińczów, s. 142.

${ }^{76}$ M. Ptaszyński, Reformacja w Polsce a dziedzictwo Erazma z Rotterdamu, Warszawa 2018, s. 632; K. Górski, Grzegorz Paweł z Brzezin. Monografia z dziejów polskiej literatury ariańskiej XVI wieku, Kraków 1929, s. 168-169.

77 Akta synodów różnowierczych w Polsce, t. 2: 1560-1570, oprac. M. Sipayłł, Warszawa 1972, s. 5; zob. też A. Kawecka-Gryczowa, Daniel z Łęczycy, s. 74.

${ }^{78} \mathrm{Na}$ jego temat zob. L. Hein, Italienische Protestanten und ihr Einfluss auf die Reformation in Polen während der beiden Jahrzehnte vor dem Sandomirer Konsens, Leiden 1974, s. 27-65; H. Barycz, Meandry Lismaninowskie, „Odrodzenie i Reformacja w Polsce”, 16, 1971, s. 37-66; T. Wotschke, Francesco Lismanino, „Zeitschrift der Historischen Gesellschaft für die Provinz Posen", 18, 1903, s. 213-332.

79 K. Estreicher, Bibliografia polska, t. 29, Kraków 1933, s. 226.

${ }^{80}$ T. Wotschke, Die Briefwechsel der Schweizer mit den Polen, Leipzig 1908, nr 276, s. 177; zob. też D. Caccamo, Eretici italiani in Moravia, Polonia, Transilvania (1558-1611). Studi e documenti, Firenze 1970, s. 92-93. Podsumowanie śladowych 
gdy przeniósłszy się do Królewca, opublikował swoją konfesję mającą oddalić go od poglądów antytrynitarskich i (bezskutecznie) doprowadzić do zgody między zwaśnionymi skrzydłami małopolskiego zboru, tworząc kompromisowe stanowisko między trydeizmem a kalwińską wizją Trójcy Świętej ${ }^{81}$. Włączony do wydanej przez Lismanina kompilacji rozmaitych pism wiersz Negriego to niedługi utwór zalecający lekturę czytelnikowi, w którym przywódca małopolskich ewangelików wychwalany jest jako pobożny minister, oponent heretyków i trynitarz. Brak szczegółowych informacji o tej paratekstowej pieśni: możliwe, że zmarły dwa lata wcześniej Negri istotnie pozostawił taki utwór przyjacielowi (dotyczący przecież kwestii dyskutowanych jeszcze od końca poprzedniej dekady), ale nie można też wykluczyć, że Lismanino podał autora fałszywie, chcąc wzmocnić wydźwięk własnego wydawanego tekstu.

Gdyby zawierzyć adresom wydawniczym, to oba wydania jedynego łacińskiego przekładu tragedii Negriego ukazały się równocześnie w Genewie i Poschiavo, za którym skrył się Pińczów. Fakt ten można próbować interpretować na kilka sposobów. Przede wszystkim nie należy wykluczać, że fałszywemu adresowi „Pesclavii” towarzyszyła także nieprawdziwa data wydania. Mogłoby to oznaczać, że tekst wydania pińczowskiego zredagowany został - wraz z drobnymi modyfikacjami i uzupełnieniami o Reju i Trzecieskim - po pewnym czasie od wydania genewskiego, czyli w kolejnych latach działalności oficyny pińczowskiej, nie później zatem niż w 1562 r.

Jak wskazują źródła, bardziej prawdopodobne jest jednak, że tekst w jakiejś postaci znajdował się już w Polsce od końca 1557 r. Na zgromadzeniu starszyzny zborowej w Pińczowie 21 października tego roku otrzymano listy od Francesca Negriego, w których dziękował za przyjęcie jego syna Giorgia, oraz przekazywał książkę swego autorstwa „o wolnej woli” („,de libero arbitrio”) ${ }^{82}$. Choć informacja jest lakoniczna, to prawdopodobieństwo, że mowa właśnie o omawianej tu tragedii, jest duże. Brak przede wszystkim wiadomości o języku dostarczonego utworu. Sformułowanie „librum sui laboris” mówi niewątpliwie o autorstwie Francesca Negriego. Sprawa komplikuje się jednak dalej: gdyby potraktować słowo „książka” jako wskazanie na tekst drukowany, tekst tragedii musiałby być dostarczony po włosku, nie było bowiem przed 1559 r. żadnego łacińskiego wydania. Jeśli dostarczono zaś utwór w przekładzie łacińskim, musiał to być rękopis. Oznaczałoby to, że prace Negriego nad autorskim przekładem, który w Genewie wytłoczono na prasach Crespina w 1559 r., musiały zacząć się co najmniej dwa lata wcześniej, by jego syn zdołał przywieźć rękopis tekstu, który jest w zasadzie - poza wskazanymi wcześniej interpolacjami - tożsamy w obu wydaniach.

Jednocześnie jeden z dodatków wydania anonimowego rozpoznanego jako pińczowski w świetle powyższych uwag nie pozostawia złudzeń co do sposobu, w jaki utwór znalazł się w Polsce. Zacytowany na początku zagadkowy fragment dedykacyjny, w którym autor zwraca się do swej książki słowami, że ma iść odważnie tam, gdzie niesie ją „Georgius Niger”, zyskuje teraz zrozumiałe uzasadnienie: stanowi ono odniesienie do tego, że to Giorgio przetransportował w jakiejś postaci podany później do druku tekst. Jednocześnie nie będzie to aluzja czytelna dla każdej osoby zaglądającej do tej książki, trudno byłoby więc sądzić, że „Pesclavii” ze strony tytułowej miałoby się odnosić np. do miejsca powstania utworu, wszak Negri rezydował w oddalonej od Poschiavo Chiavennie. Ponadto składnia i konstrukcja dwuwiersza zaciemnia raczej związek słów „Georgius” i „Niger”, rozbijając oba wyrazy na dwa wersy

informacji o pobycie Negriego w Polsce dał ostatnio V. Vozza, Francesco Negri da Bassano. Aggiornamenti bio-bibliografici e nuovi percorsi di ricerca sul monaco benedettino passato alla Riforma, „Protestantesimo. Rivista della Facoltà Valdese di Teologia", 71, 2016, nr 4, s. 379-383.

${ }^{81}$ Ad candidum lectorem Francisci Nigri Bassanensis carmen, w: F. Lismanino, Brevis explicatio doctrinae de Sanctissima Trinitate, b.m.w. 1565, k. $\mathrm{F}_{8} \mathrm{v}-\mathrm{G}_{1}$ r. Na podstawie dat pojawiających się w druku przypuszcza się, że być może nie było to pierwsze wydanie; zob. T. Wotschke, Francesco Lismanino, s. 296-297; zob. też Antitrinitarische Stretigkeiten. Die tritheistische Phase (1560-1568), red. I. Dingel, oprac. K. Daugirdas, Göttingen 2013, s. 179-180 (edycja Brevis explicatio: tamże, s. 185-222); S. Kot, Andrzej Frycz Modrzewski. Studium z dziejów kultury polskiej, Kraków 1919, s. $229-232$.

${ }^{82}$ H. Dalton, Beiträge zur Geschichte der evangelischen Kirche in Russland, t. 3: Lasciana nebst den ältesten evang. Synodalprotokollen Polens 1555-61, Berlin 1898, s. 445 (Acta congregationis Pinczoviae celebratae anno 1557, diebus vero XVIII-XXII Octobris): „Litterae offerebantur missae ad ecclesiam a Francisco Nigro Basianensi, in quibus egit gratias pro humanissima tractatione et expertione sui filii Gregorii Nigri, gratulatusque est revelatam esse evangeliam Iesu Christi in nostra Polonia; praeterea offerebat loco gratitudinis suae librum sui laboris de libero arbitrio. Haec omnia ecclesia grato suscepit". 
oraz oddzielając je czasownikiem i zaimkiem. „Pesclavii” ze strony tytułowej stanowi więc maskę, chociaż pozostawiono w dedykacyjnym paratekście aluzyjny klucz.

W tym kontekście warto wspomnieć o dwóch utworach, których okoliczności wydania w Polsce również pozostają nie do końca wyjaśnione, ale zbliżone pod względem źródłowego kręgu religijnego. Oba powstały pod piórem Bernardina Ochina, innego włoskiego teologa przebywającego wówczas w Zurychu, bliskiego zresztą Negriemu. W literaturze wysuwano podejrzenia, że oprócz wspomnianych listów od teologów szwajcarskich (wydanych w 1559) i zakupów do biblioteki króla Zygmunta Augusta Lismanino przywiózł ze swojej podróży w latach 1553-1556 także nieznane bliżej rękopisy, na podstawie których dokonano dwóch przekładów ${ }^{83}$. Niezachowana $O$ zwierzchności papieskiej trajedyja wydana została przez Aleksandra Aujezdeckiego w Szamotułach w 1558 r., a jej przypuszczalnym thumaczem był królewiecki działacz luterański Eustachy Trepka. Znał go niewątpliwie Lismanino, podejrzewany zresztą przez Małopolan o zbyt serdeczne kontakty z pruskimi reformatorami ${ }^{84}$. Nie jest znane żadne łacińskie ani włoskie wydanie tego utworu, a jedynie angielskie. Według Juliusza Kleinera przekładu polskiego dokonano z niezachowanego dziś manuskryptu łacińskiego lub włoskiego, wykluczyć można bowiem znajomość angielskiego przez Trepkę ${ }^{85}$. Wydaną zaś w 1560 r. w Pińczowie Trajedyję o Mszej już tu wspomniano i związek polskiego wydania z działalnością Lismanina nie ulega wątpliwości ${ }^{86}$. Warto jednak zaznaczyć, że utwory Ochina, których trawestacją jest polska Trajedyja o Mszej, ukazały się w wersjach kontrolowanych przez autora dopiero w 1561 r., a zatem wydanie polskie powstało na podstawie wcześniejszej redakcji tekstu w manuskrypcie ${ }^{87}$.

Wiele wskazuje zatem na to, że obie Ochinowe tragedie, podobnie jak utwór Negriego, zostały przywiezione w rękopiśmiennej redakcji przygotowanej przez autora, by służyć za podstawy tłumaczeń, w Szwajcarii ukazała się zaś łacińska i włoska wersja tylko jednego z tych dwu utworów. Pokazuje to, że znane są już przypadki kolportażu rękopisów utworów pisanych przez autorów rezydujących w Szwajcarii, a następnie wydawanych w Polsce, czy to w przekładzie, czy po łacinie. Związek pomiędzy tragediami Ochina i Negriego rozgrywa się także na płaszczyźnie literacko-gatunkowej. Obaj autorzy uprawiali bardzo specyficznie rozumiany gatunek tragedii, który służył im do eksplikacji antyrzymskich polemik za pomocą alegorycznych personifikacji (przy czym to Ochino, bezpośrednio współpracujący z Negrim, wzorował się na rozwiązaniu Bassańczyka, pisząc swoje utwory). Warto podkreślić, że zastosowana przez obu formuła gatunkowa wyróżniała się na tle religijnej produkcji literackiej tego czasu i jest postrzegana jako osobne zjawisko zrodzone w określonym kręgu religijnym ${ }^{88}$. Przygotowanie edycji Negriego w Pińczowie można by widzieć jako komplementarne do wydania przez Lismanina tragedii Ochinowych w Szamotułach i Pińczowie. Dzięki temu czytelnikowi polskiemu dostarczono pełen korpus „tragedii” odpowiadających sobie pod względem formalnym i literackim, a także uzupełniających się poruszanymi tematami.

${ }^{83}$ H. Barycz, Lismanin Franciszek, w: PSB, t. 17, Wrocław 1972, s. 468; A. Kawecka-Gryczowa, Biblioteka ostatniego Jagiellona. Pomnik kultury renesansowej, Wrocław 1988, s. 71-72. Na temat tragedii Ochina zob. J. Ślaski, Le „,Tragedie” di Bernardino Ochino in polacco, w: Movimenti ereticali in Italia e in Polonia nei secoli XVI-XVII. Atti del convegno italo-polacco, Firenze, 22-24 settembre 1971, Firenze 1974, s. 103-117; J. Kleiner, „Tragedye” Ochina, „Pamiętnik Literacki”, 9, 1910, z. 4, s. 397-418.

${ }^{84}$ H. Barycz, Lismanin Franciszek, s. 467.

${ }^{85}$ B. Ochino, Tragoedie or dialoge of the unjuste usurped primacie of the Bishopof Rome, and of all the just abolishyng of the same, thum. J. Ponet, London 1549 (zob. dwa warianty wydania o nr. 18770, 18771 w: A.W. Pollard, G.R. Redgrave, Short Title Catalogue, wyd. 2, London 1976-1991, <http://estc.bl.uk> [dostęp: 19.05.2021]).

${ }^{86}$ J. Kleiner, ,Tragedye” Ochina, s. 409-417.

87 B. Ochino, Disputa intorno alla presenza del corpo di Giesu Christonel sacramento della cena, Basilea 1561 (VD16: O 207); tenże, Liber de corporis Christi praesentia in coenae sacramento, Basileae 1561 (VD16: O 208).

${ }^{88}$ Do zasadniczych zbieżności należy przede wszystkim wprowadzenie za pomocą formalnych cech układu zdarzeń tragedii perspektywy apokaliptycznej i wykorzystanie gatunku do ukazania logiki dziejów oraz cechującego owych autorów przekonania o panowaniu Antychrysta; zob. R. Leo, Tragedy as Philosophy in the Reformation World, Oxford 2019, s. 53-61. Wzoru utworom Negriego i Ochina miała dostarczyć formuła tragedii Thomasa Kirchmeyera (Naogeorga), zwłaszcza Pammachius (Wittenbergae 1538), a do grona autorów stosujących takie rozwiązanie, nie bez prawdopodobnych związków z owymi Włochami, zaliczyć można także Johna Foxe’a z jego tragedią Christus triumphans (Londinii 1551; Basilae 1556). 
Otwarte musi pozostać pytanie, kto jest autorem uzupełnień wydania polskiego. Zamykająca druk parafraza psalmu nie jest związana z samą tragedią i nie odwołuje się do niej w żaden sposób, co samo w sobie nie jest oczywiście niczym zaskakującym i znajduje liczne analogie w innych drukach. Możliwe, że Lismanino zebrał od Negriego kilka takich okolicznościowych utworów, by załączać je podobnie jak uczynił zresztą później w Brevis explicatio - do obszerniejszych tekstów. Czy uzyskał je w Szwajcarii bezpośrednio od autora, czy też otrzymał je zbór wraz z listami od syna w 1557 r. pozostanie zapewne nierozstrzygnięte. Kosmetyczne zmiany w liście dedykacyjnym w pińczowskim Liberum Arbitrium wyglądają raczej na dzieło osoby zorientowanej lepiej w warunkach polskich niż osiadły w odległej Gryzonii Negri i można by uznać je za korekty dostosowujące pierwotne brzmienie tekstu do lokalnej etykiety i hierarchii. Amplifikacje zaś służące pochwale Reja i Trzecieskiego ocenić najtrudniej: można wprawdzie wyobrazić sobie, że odpowiednio poinformowany Negri skreślił samodzielnie kilka słów o poleconych mu postaciach i wkomponował je w swój wcześniejszy utwór. Intryguje jednak cel owych uzupełnień, niezależnie od ich potencjalnego autora: czy to Lismanina, czy to Giorgia Negriego (znającego Trzecieskiego syna Francesca), czy też innej osoby z kręgu pińczowskiego.

Warto zapytać o możliwe przyczyny ukrycia nazwiska drukarza. Tragedia Negriego, w której krytyka papieskiego Rzymu wychodzi na pierwszy plan poza czysto teologicznymi kwestiami, znalazła się oczywiście na indeksach rejestrujących prohibita (od 1549 r. począwszy) ${ }^{89}$. W „katalogu heretyków” Piera Paola Vergeria z 1556 r. obok tytułu tragedii - w dotychczasowych indeksach figurującej jeszcze jako zanonimizowana (autora wskazano wyłącznie pod inicjałami F.N.B.) - reformator umieścił nazwisko Negriego, by imiennie wskazać na niego pośród innych zakazanych autorów i dzieł, ukazując ich jednak jako świadków prawdziwej wiary ${ }^{90}$. Nie pozostaje to jednak w zgodzie z innymi decyzjami Daniela z Łęczycy: sygnował druki, w których występowały nazwiska autorów takich jak Melanchton, Modrzewski czy Ochino, choć i oni występowali w tych samych indeksach co Negri. Wątpliwe wydaje się zatem, by decyzji tej przyświecała chęć uniknięcia konfrontacji z władzami kościelnymi. Nie wydaje się również, by niesnaski wewnątrz zboru nakazywały ukrycie wydawcy. Negri nie przemyca w swoim utworze żadnej myśli antytrynitarskiej czy anabaptystycznej, brak w nim też odniesień aprobatywnych czy polemicznych do poglądów Stancara w kwestii Trójcy Świętej, tak intensywnie dyskutowanych w Pińczowie w 1559 r. Pewną ewentualność stanowi jednak możliwe skojarzenie z tym, że syn Negriego, Giorgio, pełniący posługę w Polsce w domu Provanów i odpowiedzialny za przekazanie manuskryptu tragedii starszyźnie pińczowskiego zboru, mógł być kojarzony ze zwalczanym Stancarem. Wraz z nim bowiem przybył do Polski w 1557 r., był rozpoznawany jako jego uczeń i zasłynął uczestnictwem wraz z Stanisławem Lasockim i Andrzejem Trzecieskim w odbiciu Stancara z więzienia w Lipowcu' ${ }^{91}$ Na pewno więc nie potencjalny konflikt z Kościołem rzymskim stał się przyczyną ukrycia nazwiska drukarza, choć mogła to być groźba eskalacji wewnętrznego konfliktu zboru małopolskiego i jego wyjścia poza krąg zgromadzenia.

Zagadkowe pozostaje zarazem wskazanie Poschiavo, nie zaś Pińczowa, w adresie wydawniczym. Czym podyktowany był ten wybór? Sfingowany adres wydawniczy „Pesclavii” mógł być swego rodzaju maską dla właściwej nazwy miejscowości. Praktyka taka znana była i stosowana szczególnie w różnowierczych ośrodkach drukarskich ${ }^{92}$. W tym wypadku mogłaby się opierać na wizualnym podobieństwie

89 Zob. indeks z 1549 r.: Index de Venise (1549), Venise et Milan (1554), oprac. J.M. de Bujanda, Sherbrooke 1987, nr 134, s. 199-200 (potępienie utworu Tragedia del libero arbitrio di F.N.B.); z 1554 r.: tamże, nr 568, s. 364 (potępienie utworu Tragedia de libero arbitrio); z 1559 i 1564 r.: Index de Rome (1557, 1559, 1564): le premiers index romains et l'index du Concile de Trente, oprac. J.M. de Bujanda, Sherbrooke 1990, nr 292, s. 465 (potępienie autora); nr 958, s. 692 (potępienie utworu Tragoedia de libero arbitrio).

90 P.P. Vergerio, Catalogus haereticorum aeditus Venetiis de commissione tribunalis sanctissimae inquisitionis [...] cum annotationibus Athanasii, Regiomonte Borrusiae 1556, k. C 7 .

91 A. Węgierski, Libri quattuor Slavoniae reformatae, wyd. J. Tazbir, Warszawa 1973, s. 228.

92 Zob. więcej: I. Wiencek, Jawne i ukryte. O wymowie kart tytułowych kilku druków polemicznych, w: Figura heretyka w nowożytnych sporach konfesyjnych, red. A. Bielak, W. Kordyzon, Warszawa 2017, s. 52-53; A. Kawecka-Gryczowa, Ariańskie oficyny wydawnicze Rodeckiego i Sternackiego, Wrocław 1973, s. 51-52. Szerzej o nowożytnych fałszerstwach wydawniczych zob. A. Grafton, Forgers and Critics. Creativity and Duplicity in Western Scholarship, przedm. A. Blair, Princeton 2019. 
do nazwy Pińczów (czy w adresach łacińskich: Pinczoviae), w mniejszym stopniu ze względu na aliteracyjną bliskość brzmienia. Niewykluczone także, że frazę „Pesclavii anno” pomyślano jako niepełny anagram łacińskiego adresu „Pinczoviae”.

Samo Poschiavo nie było dużym ani szeroko znanym ośrodkiem wydawniczym. Ze względu jednak na położenie tuż przy północnej granicy Lombardii stało się atrakcyjnym punktem pozwalającym na kolportaż „heretyckich” pism do Italii. Pierwszą drukarnię w regionie założył Dolfino Landolfi, aktywny w latach 1549-1560. To on współpracował z działającymi wówczas w Szwajcarii włoskimi pisarzami heterodoksyjnymi. W owym czasie z pras Landolfiego schodziły dzieła takie jak włoski przekład rozprawy Heinricha Bullingera o soborze trydenckim (1551), Annotomia della messa Agostina Mainardiego (1552), anonimowa historia o protestanckim męczenniku Giuliu da Milano (1552) czy De amplitudine beati regni Dei dialogi Celia Secunda Curionego (1554). Przeważnie jednak miejsca wydania ani nazwisko drukarza nie były w tych drukach wskazywane, a atrybucje zostały dokonane później przez badaczy. Szesnastowieczny czytelnik zatem najpewniej nie zdawał sobie sprawy, skąd książki te pochodziły, ani nie kojarzył z nimi miejscowości Poschiavo. „Pesclavii” na karcie tytułowej nosiło za to jedno dzieło Negriego, mające charakter edukacyjny, a nie polemiczno-religijny, czyli Canones grammaticales ${ }^{93}$. Negri prowadził szkołę w nieodległej Chiavennie i niewykluczone, że publikacja miała znaleźć tam zastosowanie ${ }^{94}$. Wydaje się jednak, że to nie z Negrim, a z Vergeriem Poschiavo mogło kojarzyć się ponadlokalnej społeczności zainteresowanej piśmiennictwem religijnym. Vergerio dbał o Landolfiego jako jednego ze swoich pierwszych wydawców, wspierając go m.in. w odpowiednim wyposażeniu jego warsztatu ${ }^{95}$. Teolog wydał na jego prasach kilkanaście pozycji, z czego w latach 1549-1552 co najmniej trzy miały w adresie wydawniczym i nazwę miejscową, i nazwisko drukarza ${ }^{96}$. Należały do nich poczytne tytuły jego autorstwa, m.in. Instruttione christiana (1549) czy pisma polemiczne jak Risposta del vescouo Vergerio ad un libro del Nausea vescouo di Vienna (1552) i Accusatione contra i papisti... (1552). Niewykluczone, że wiedza o Poschiavo jako miejscowości potencjalnie dającej skojarzyć się z Vergeriem i kręgiem protestantów włoskich w Szwajcarii miała też związek zarówno z intensywną wymianą korespondencji z Polską i Prusami, jak i z pobytami teologa w latach 1556-1557 oraz 1559, gdy i Laski, i Lismanino odbyli z nim co najmniej kilka spotkań. Kontakty te nie zawsze były zresztą owocne, gdyż Vergerio pozostawał z Łaskim w sporze ${ }^{97}$. Współpracował też raczej z działaczami prusko-wielkopolskimi (luterańskimi) i opublikował kilka pism w królewieckiej oficynie Hansa Daubmanna w latach $1554-1563^{98}$. Choć sprawia to, że włoski eksbiskup jawi się jako mniej wiarygodny współpracownik pińczowian i Lismanina (który jednak, nawet pozostając formalnie po stronie Łaskiego, mimo to utrzymywał zapewne mniej lub bardziej oficjalne kontakty z Królewcem, a przy tym być może i z Vergeriem), to wysoce prawdopodobne, że wiedza o działalności niegdysiejszego nuncjusza papieskiego była powszechna w kręgach różnowierczych.

Przy tak ambiwalentnych stosunkach Małopolan z Vergeriem należy wziąć pod uwagę, że użycie „Pesclavii” w adresie wydawniczym miało zapewne obudzić szersze skojarzenia niż tylko postać konkretnego reformatora. Być może zadziałał tu podobny mechanizm jak w przypadku opisanym przez E. Barbieriego ${ }^{99}$. Rzecz dotyczy wcześniejszego włoskiego wydania tragedii Negriego z 1547 r. Egzemplarz, który znalazł się w Cambridge, ma stronę tytułową z adresem wydawniczym „In Poschiavo". Jak wykazał E. Barbieri, poza pierwszą kartą jest on jednak identyczny pod względem typograficznym

${ }^{93}$ F. Niger, Canones grammaticales, sive latina syntaxis..., Pesclavii 1555.

${ }^{94}$ C. Casalini, L. Salvarani, Introduzione, w: F. Negri, Tragedia, s. 28; zob. też M. Taplin, The Italian Reformers and the Zurich Church, c 1540-1620, London 2016, s. 40-41.

95 R.A. Pierce, Pier Paolo Vergerio the Propagandist, Roma 2003, s. 74-75.

${ }^{96}$ Censimento nazionale delle edizioni italiane del XVI secolo, $<$ http://edit16.iccu.sbn.it/> [dostęp: 19.05.2021]: CNCE 72104, CNCE 72142, CNCE 72145. Pozostałe zob. tamże: CNCE 54143, CNCE 69773, CNCE 72114, CNCE 72137, CNCE 72141, CNCE 72202, CNCE 72207, CNCE 72307, CNCE 72314, CNCE 79922.

97 L. Hein, Italienische Protestanten, s. 54-55; H. Kowalska, Działalność reformatorska, s. 52-53, 79-80.

98 VD16: V 670; K 465; K 175; G 3130; L 1981; F 1874; B 7793; V 635; R 1757; L 1982; K 176; V 680; V 642.

${ }^{9}$ E. Barbieri, Un fantasma bibliografico inglese: F. Negri, “Tragedia del libero arbitrio”, Poschiavo 1547, „La Bibliofilía”, 97,1995, nr 3, s. 267-290. 
$\mathrm{z}$ anonimowym, ale rozpoznanym jako weneckie, wydaniem $\mathrm{z}$ tego samego roku. Badacz przekonuje, że karta tytułowa egzemplarza z Cambridge dodrukowana została pod koniec XVI w., gdy książka już znajdowała się w Anglii, a adres wydawniczy sfingowano, odwołując się do rozpowszechnionego przekonania, znajdującego potwierdzenie $w$ innych drukach angielskich i dokumentach z epoki, że Poschiavo jest swoistym stypizowanym miejscem wskazującym na heterodoksję religijną ${ }^{100}$. Choć brak analogicznych i jednoznacznych materiałów wskazujących konwencjonalność takiego odniesienia w kręgach polskich, to jednak należy dopuszczać i zamierzoną jednorazowo aluzyjność adresu pińczowskiego druku.

Najważniejsze w doborze nazwy miejscowej w tym wypadku wydaje się to, że Poschiavo znajduje się poza Polską, a zatem czytelnik mógł mieć wrażenie, że ma w rękach importowaną publikację zagraniczną. Skojarzenia $z$ helwecką reformacją, a być może i publikacjami Vergeria zawierającymi nazwę tej miejscowości $\mathrm{w}$ adresie wydawniczym, miały tylko wesprzeć przemycane $\mathrm{w}$ tym druku tezy. Zasadniczy jednak cel sfingowania nazwy miejsca wydania ujawnia się w powiązaniu jej z dodanymi w Pińczowie wzmiankami o Reju i Trzecieskim. O ile inne druki z 1559 r. wymierzone przeciwko Stancarowi wyrażały wsparcie zagranicznych teologów w konkretnej polemice, o tyle tragedia Negriego była przeznaczona dla szerszego kręgu czytelników (oczywiście wciąż na tyle wykształconych, by czytać po łacinie, ale niekoniecznie na tyle zaangażowanych w życie zborowe, by zajmować się wewnętrznymi rozbieżnościami w stanowiskach doktrynalnych) w ramach stałej akcji perswazyjnej, mającej pozyskać nowych zwolenników dla reformacji. Utwór Negriego wydany w Pińczowie - poza potencjalnymi walorami edukacyjnymi i informacyjnymi - miał przekonywać o głębokim szacunku zagranicznego autora dla działań i cnót pisarzy kojarzonych z reformacją w Polsce. Wydanie to stanowiło zatem poniekąd reklamę dla działalności tak Trzecieskiego i Reja, jak i całego ich środowiska: druk dawał wrażenie, że ich sława sięgnęła samej Szwajcarii, jednego z kluczowych centrów reformacji w Europie, a ich wypowiedzi ceni się na tyle, że powołują się na nie imiennie bohaterowie głoszącego protestanckie postulaty utworu. Warto przy tym zauważyć, że to fałszerstwo wydawnicze oparte zostało także na racjonalnym założeniu, że druki ze znanych ośrodków wydawniczych, jak Genewa czy Bazylea, mogły być skądinąd czytelnikom znane, wybrano zatem miejscowość o mniejszej randze (choć potencjalnie mogącą wywoływać wskazane wcześniej pożądane skojarzenia), by rozpracowanie tej mistyfikacji uczynić nieco trudniejszym zadaniem.

Poszukiwanie osób odpowiedzialnych za doprowadzenie do wydania tego utworu w Polsce opierać się może niestety jedynie na poszlakach. W ostatecznych konkluzjach podkreślić należy więc potencjalną rolę dwóch postaci. Po pierwsze, Francesca Lismanina można by widzieć w roli inspiratora tego utworu, który wpisuje się w krąg publikacji, jakim patronował on w latach 1558-1560 (zwłaszcza Ochina). Po drugie, przypuszczać można o jakimś bliżej nieokreślonym udziale w tym przedsięwzięciu Giorgia Negriego, syna autora tragedii, który najpewniej odpowiedzialny był za dostarczenie tekstu do kraju, a także wskazać należy jego bliskie związki z niektórymi rezydującymi w Polsce działaczami wzmiankowanymi w druku (Provaną, Trzecieskim), zapewne nieprzypadkowo wybranymi. Biorąc zaś pod uwagę, że Francesco Negri kilka lat później (zapewne w 1563 r.) przybył do kraju na zaproszenie zboru małopolskiego, można by widzieć tak przygotowane wydanie Liberum Arbitrium - zawierające „zagraniczną” pochwałę polskich pisarzy reformacyjnych - jako swoiste przygotowanie do tej podróży, mające zapewnić ciepłe przyjęcie.

Celem niniejszej części było wskazanie na takie kluczowe obszary funkcjonowania zboru pińczowskiego, które powiązać dało się z jego działalnością wydawniczą i kampanią wyznaniowej perswazji. Pozwoliło to pokazać, w jakim kontekście funkcjonował anonimowy druk Liberum Arbitrium, jednocześnie służąc uprawdopodobnieniu zaproponowanej atrybucji. Ze względu na niedostatek świadectw źródłowych niektóre postawione pytania mają otwarty charakter i stanowią próbę rozpatrzenia możliwych zależności pomiędzy znanymi faktami a niewyeksplikowanymi celami szczegółowymi proreformacyjnych działań perswazyjnych. Dotyczy to przede wszystkim funkcji tekstowych amplifikacji w polskim, przypuszczalnie pińczowskim, niesygnowanym wydaniu Liberum Arbitrium wobec tekstu znajdującego się w wydaniu genewskim.

100 Tamże. 
L $\quad$ I $B$ E $R$ R A R B $I=$

$$
\text { T R I V M, }
$$

T R A G OE D I A Francifci $\mathcal{X}$ igri Baffanenfis.

Nunc primùm ab ipfo Authore Latinè frripta $\&$ edita.

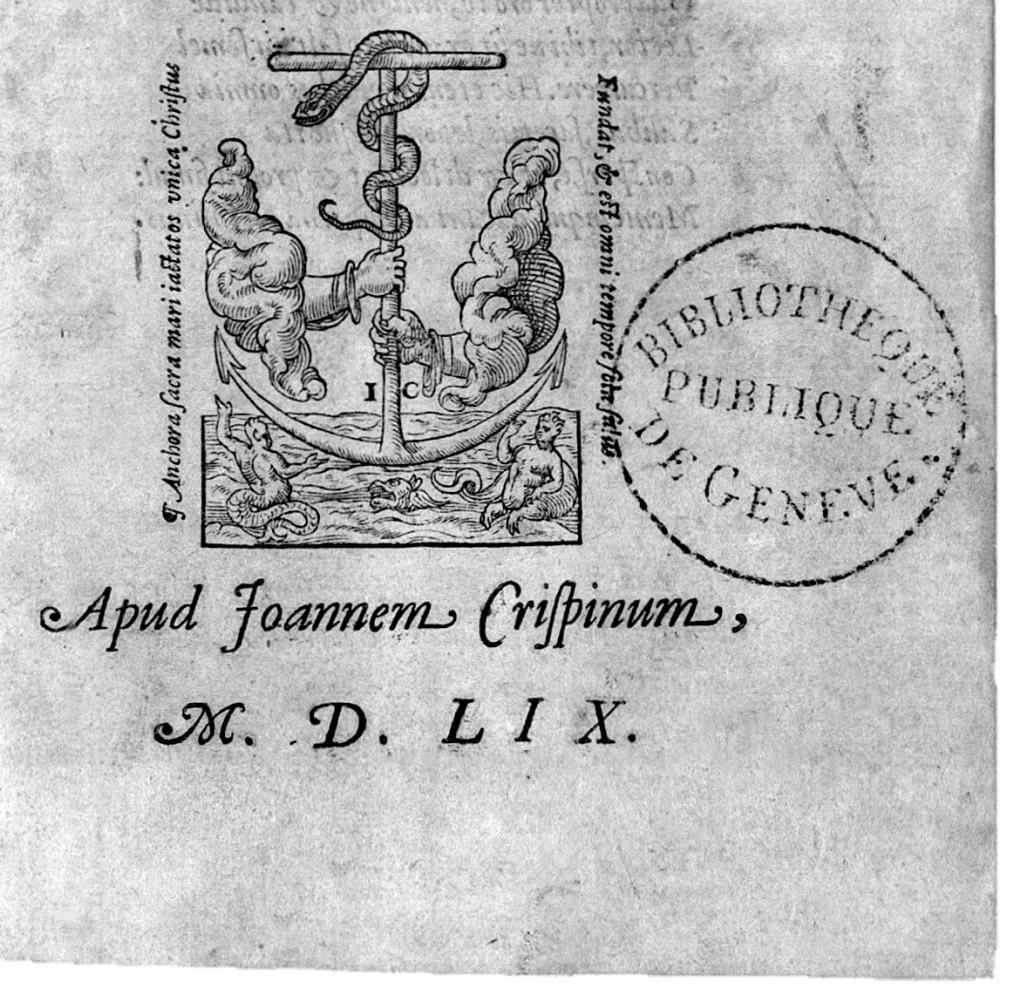

Il. 1. F. Negri, Liberum Arbitrium tragoedia, [Genewa]: Jean Crespin, 1559. Recto karty tytułowej. Bibliothèque de Genève, sygn. Hg 404 


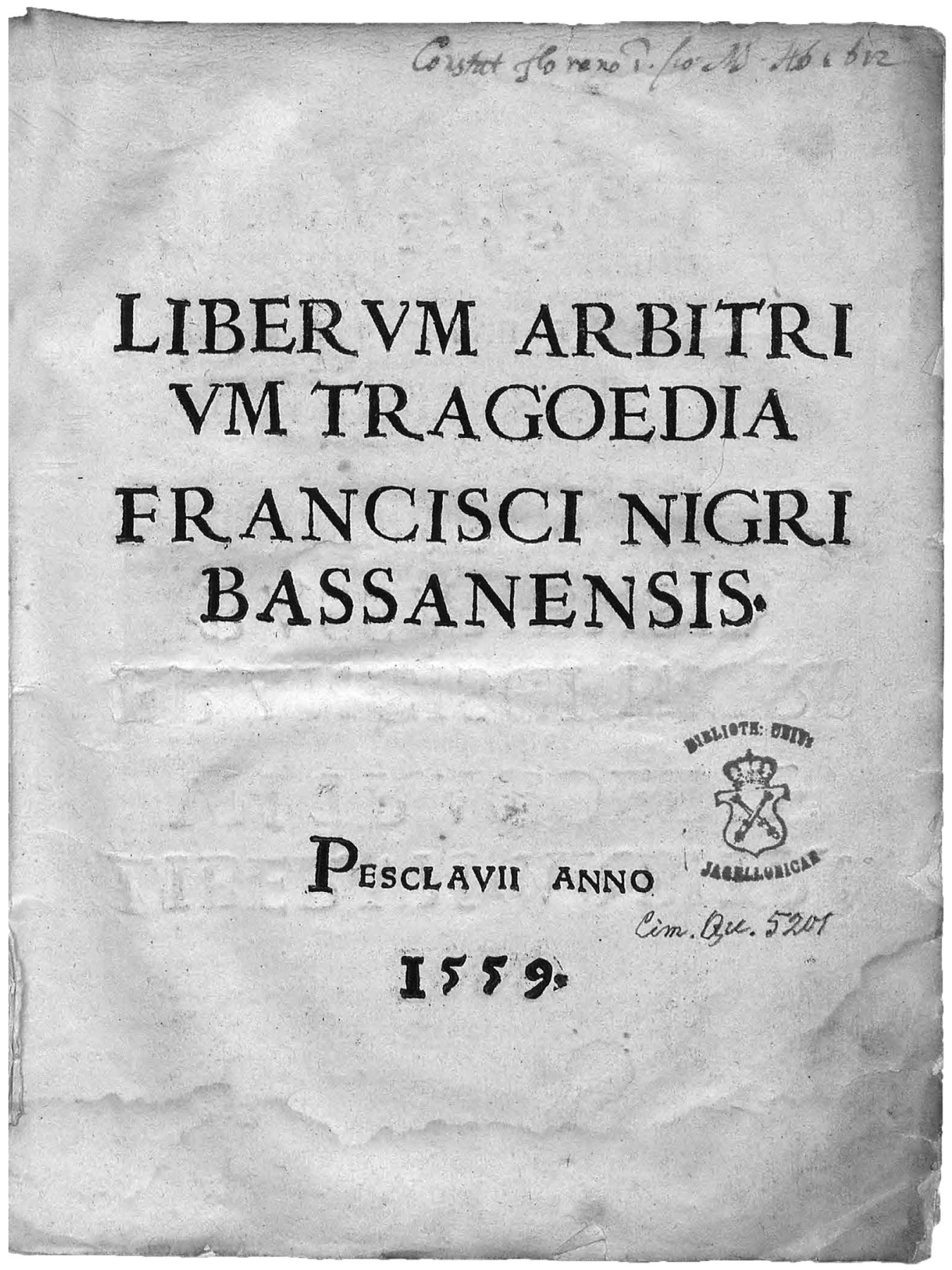

Il. 2. F. Negri, Liberum Arbitrium tragoedia, Poschiavo: [s.n.], 1559. Recto karty tytułowej. BJ, sygn. St. Dr. Cim. 5201 


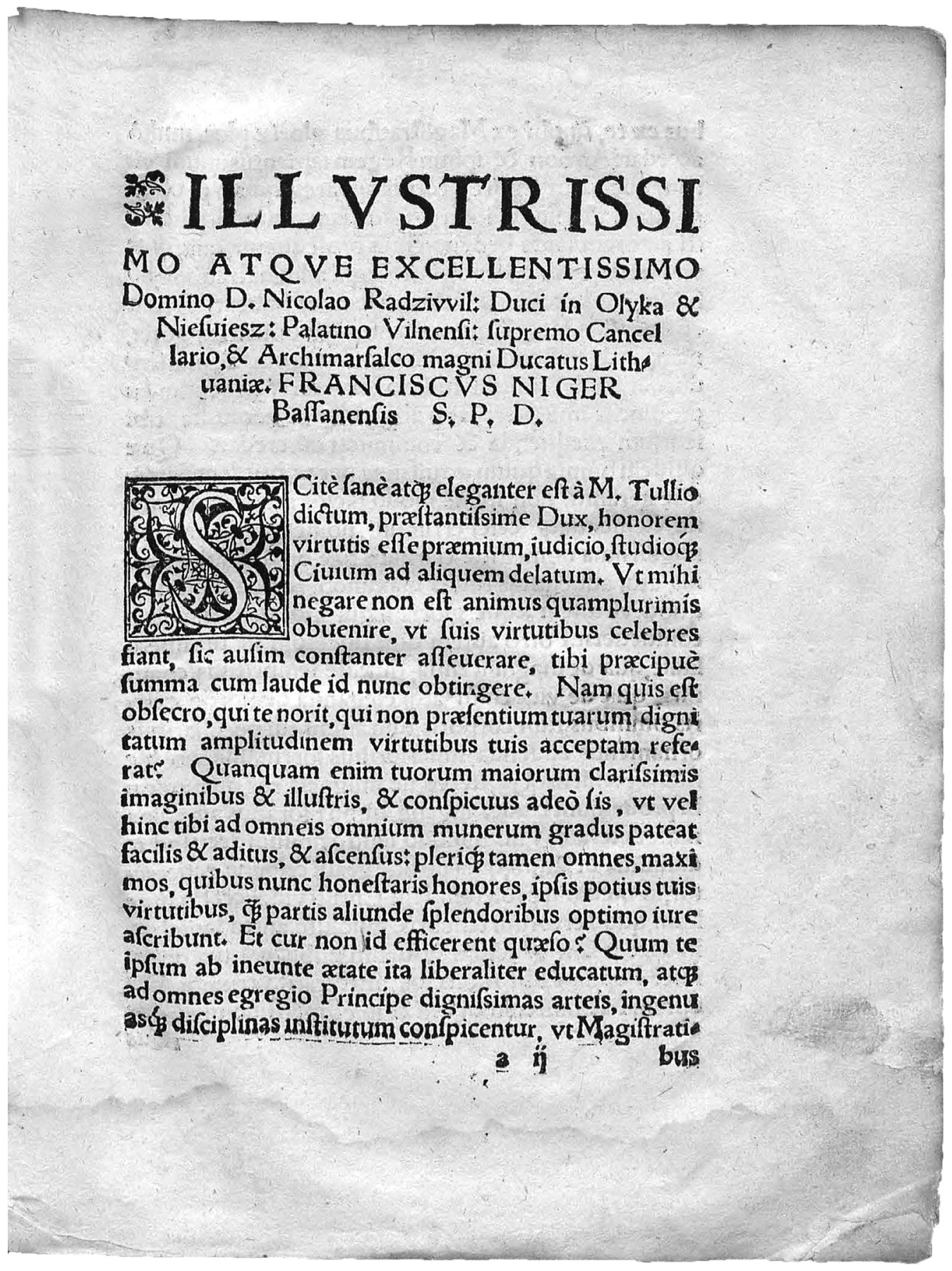

Il. 3. Strona z inicjałem „S”; F. Negri, Liberum Arbitrium tragoedia, Poschiavo: [s.n.], 1559, k. a r. BJ, sygn. St. Dr. Cim. 5201 


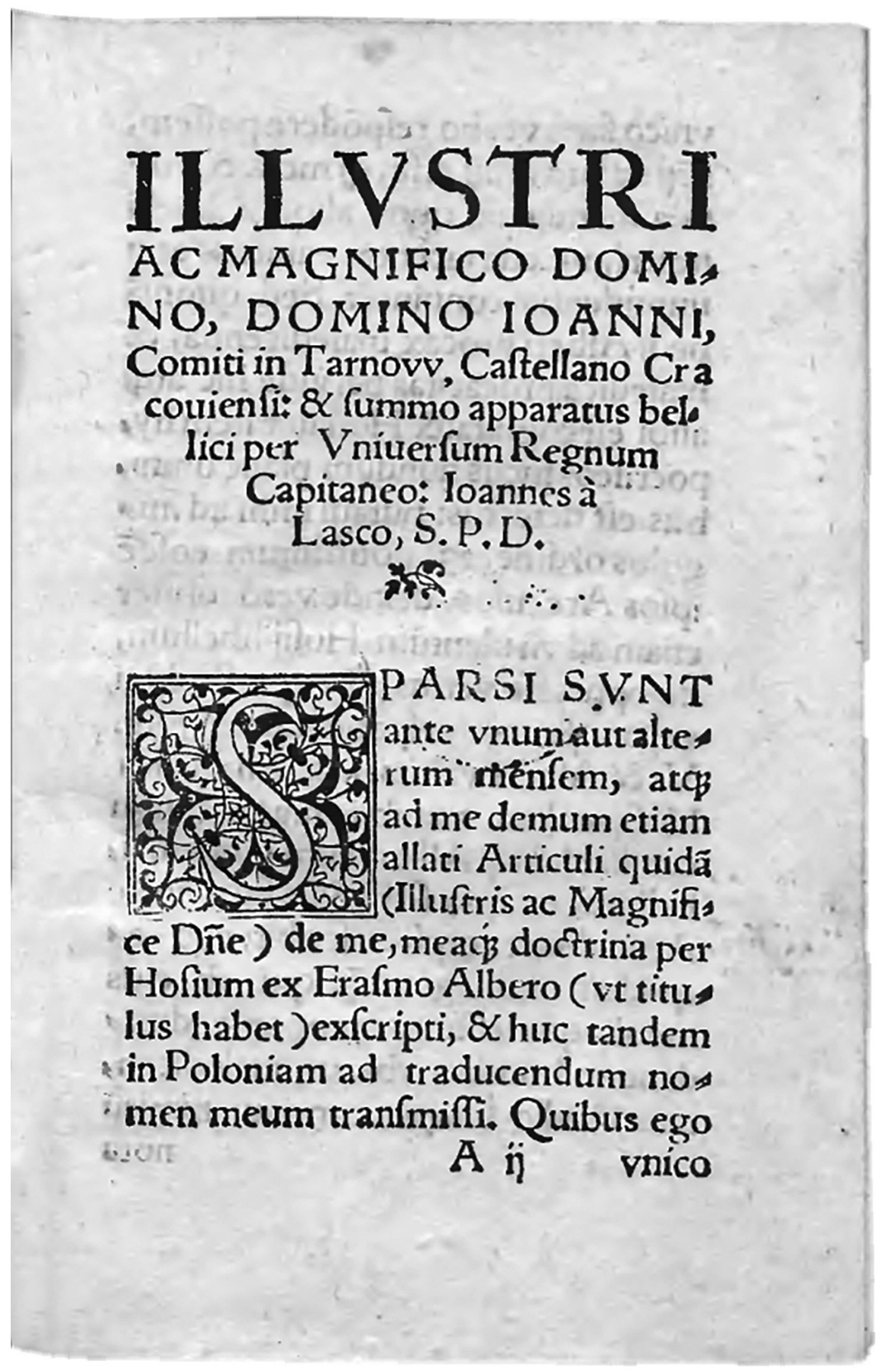

Il. 4. Strona z inicjałem „S”; J. Łaski, Brevis ac compendiaria reponsio ad collectos certos [...] articulos, Pińczów: Daniel z Łęczycy, 1559, k. A2r. BOss., sygn. XVI.O.1097 
Aneks 3. Zestawienie inicjałowych klocków drzeworytowych Daniela z Łęczycy, Jana Karcana i Łazarza Andrysowica

Tabela 1. Zestawienie odbić z klocków pochodzących z zestawów Daniela z Łęczycy i Jana Karcana (strzałkami oznaczono różnice w cięciu klocków świadczące o istnieniu dwóch zestawów)

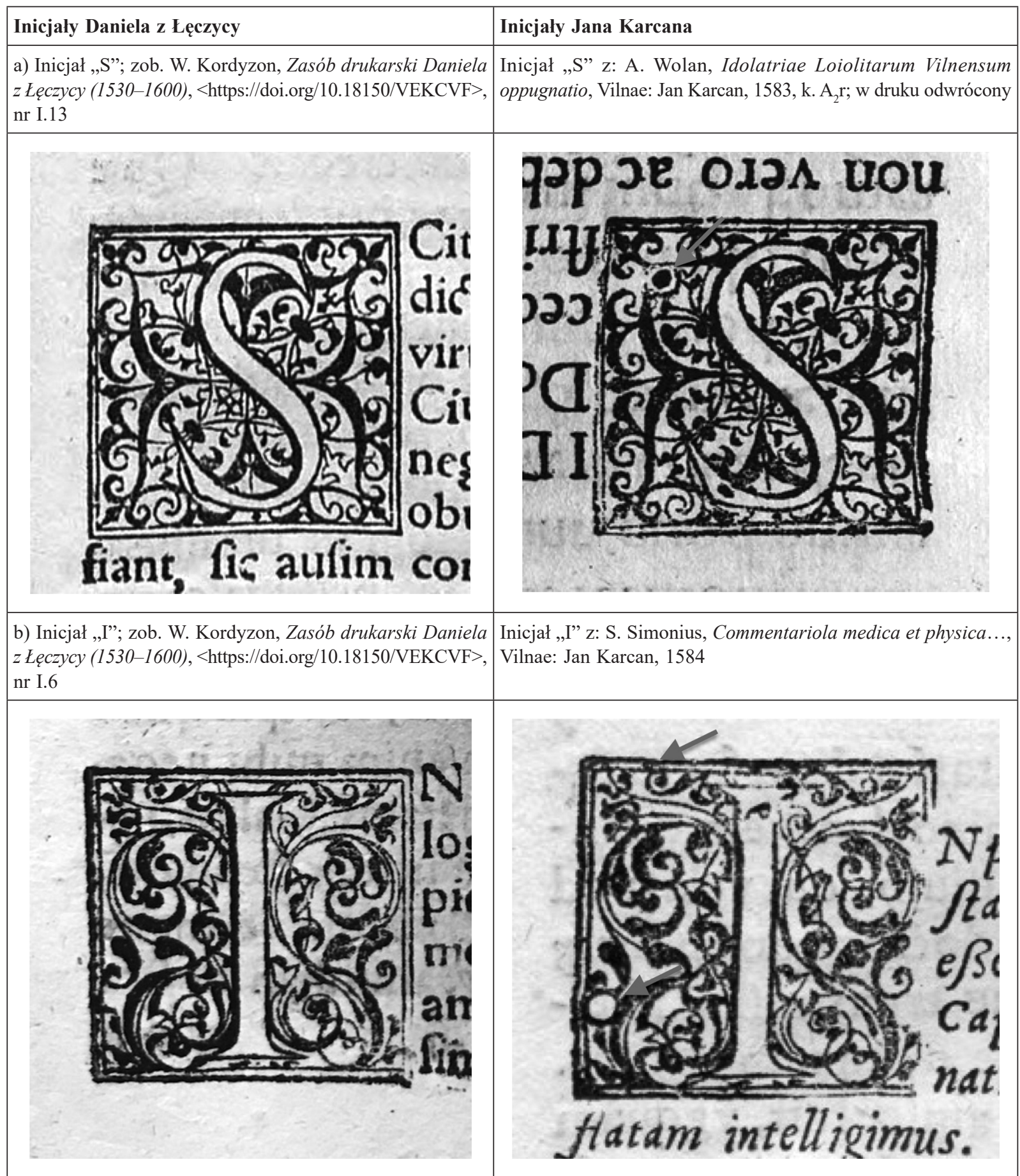


Tabela 2. Zestawienie odbić z klocków pochodzących z zestawów Daniela z Łęczycy i Łazarza Andrysowica (strzałkami oznaczono uszkodzenia świadczące o istnieniu dwóch zestawów klocków)

a) Inicjały „S”; zob. W. Kordyzon, Zasób drukarski Daniela z Łęczycy (1530-1600), <https://doi.org/10.18150/VEKCVF>, nr I.13
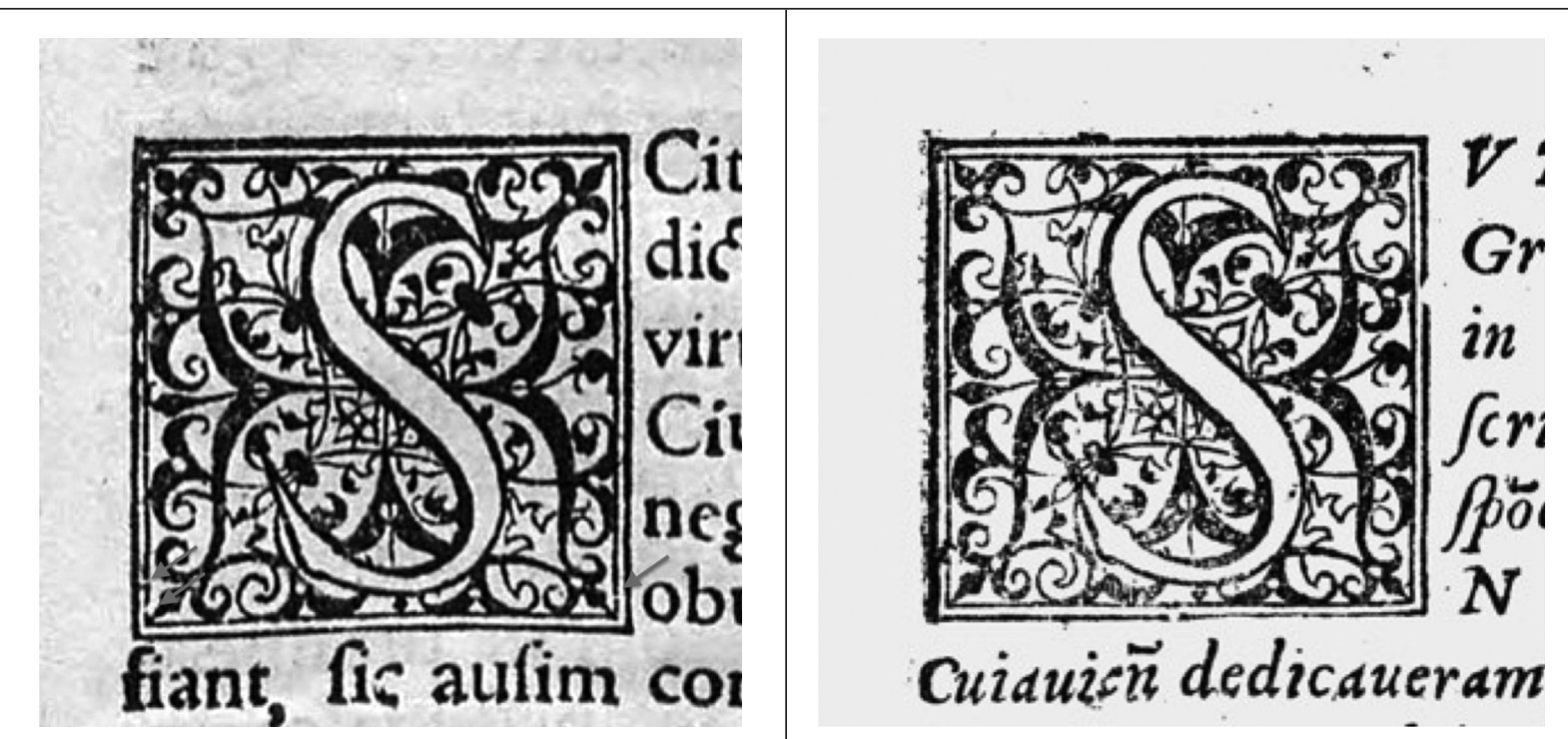

b) Inicjały „Q”; zob. W. Kordyzon, Zasób drukarski Daniela z Łęczycy (1530-1600), <https://doi.org/10.18150/VEKCVF>, nr I.12

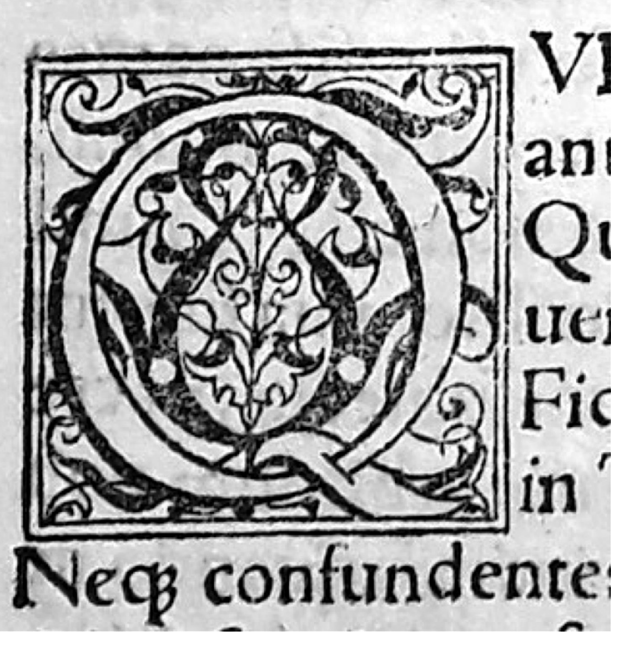

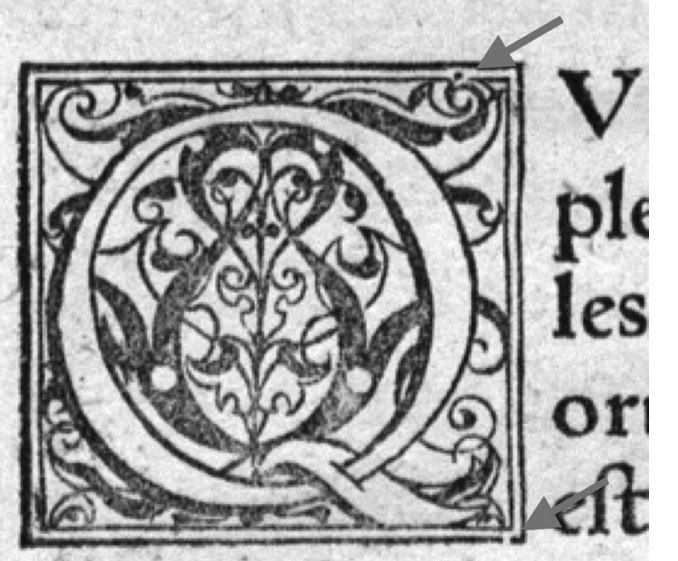

vt mandata eius c 
Aneks 4. Zestawienie próbek pisma drukowanego z druku „Poschiavo” 1559 oraz wydań sygnowanych przez Daniela z Łęczycy

\section{Majuskułowa litera „Q”}

1. „Poschiavo" 1559

A. Francesco Negri, Liberum Arbitrium tragoedia, Pesclavii: [s.n.], 1559, k. (egz. BJ, sygn. St. Dr. Cim. 5201):

\section{k. A $_{4}$ Quapropter k. B $_{2}$ Quid i k. ${ }_{1}$ r Quo}

\section{Daniel z Lęczycy}

A. Jan Łaski, Brevis ac compendiaria reponsio ad collectos certos [...] articulos, Pinczoviae 1559 (egz. BOss., sygn. XVI.O.1097):
k. $\mathrm{A}_{2} \mathrm{r}$

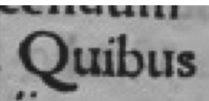
k. $\mathrm{A}_{3} \mathrm{r}$

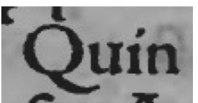
k. $\mathrm{A}_{6} \mathrm{~V}$

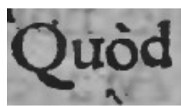

B. Exemplum literarum Ecclesiae Tigurinae ad Ecclesias Polonicas, Pinczoviae 1559 (egz. BN, sygn. SD XVI.O.92):
k. $\mathrm{C}_{2} \mathrm{r}$ Quod
k. ${ }_{8} \mathrm{r}$ Quiod
k. $\mathrm{D}_{2} \mathrm{r}$

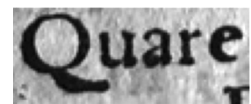

C. Filip Melanchton, Responsio de controversiis Stancari, Pinczoviae 1559 (egz. BN, sygn. SD XVI.O.54):
k. $\mathrm{A}_{6} \mathrm{r}$ Quiefcente
k. $\mathrm{A}_{7} \mathrm{v}$
Quanquam
k. $\mathrm{A}_{8} \mathrm{r}$

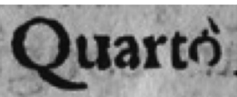

D. Krzysztof Warszewicki, De origine et derivatione generis et nomimis [sic] Polonici dialogus, Vilnae 1580 (egz. BCzart., sygn. 241 II Cim):
k. $\mathrm{A}_{2} \mathrm{~V}$

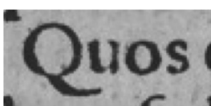
k. $\mathrm{A}_{4} \mathrm{v}$

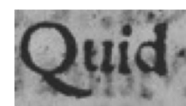
k. $\mathrm{B}_{2} \mathrm{r}$

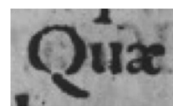




\title{
On the Polish edition of Liberum Arbitrium by Francesco Negri and 'foreign' praise of Polish Reformation writers
}

\begin{abstract}
Summary: The article analyses the 1559 edition of Liberum Arbitrium by Francesco Negri da Bassano. The publishing address of "Pesclavii" (Poschiavo) has been considered false and, based on an analysis of woodcut initials and the identification of watermarks on the printing paper, it is indicated that the print sine nomine was most probably made by the printing house of Daniel of Łęczyca at Pińczów. This edition is compared with the 1559 Geneva edition of the same text by Jean Crespin's typography. Textual differences are pointed out (minor modifications of paratexts and supplements to the Pińczów edition with the fragments that included Polish Reformation writers, Andrzej Trzecieski and Mikołaj Rej). Moreover, the author discusses the possible place of the text within the publishing programme of the Lesser Poland Protestant community Protestant around 1559, and the characters probably associated with the anonymous edition of the tragedy (especially Francesco Lismanino and Giorgio Negri) as well as possible reasons for the falsification of the publishing address, together with their potential propaganda significance for the Reformation movement in the Polish-Lithuanian Commonwealth.
\end{abstract}

Nota o autorze: Wojciech Kordyzon - asystent na Wydziale Polonistyki Uniwersytetu Warszawskiego, w latach 2019-2021 pracował na Wydziale „Artes Liberales” UW w ramach konsorcjum RESILIENCE (Religious Studies Infrastructure: Tools, Experts, Connections and Centers). Kieruje indywidualnymi projektami badawczymi: Więcej niż propaganda. Polskojęzyczny program wydawniczy w Królewcu jako projekt edukacji religijnej i kulturalnej (ok. 1544-1575) (Narodowe Centrum Nauki, nr 2020/37/N/HS2/00467) oraz Stulecie sporu, stulecie dialogu. Bernardino Ochino i protestancki dialog polemiczny w Polsce XVI wieku (program MNiSW „Diamentowy Grant", nr DI2016003546).

Author: Wojciech Kordyzon - research assistant at the Faculty of Polish Studies, University of Warsaw. In 2019-2021, he worked at the Faculty of 'Artes Liberales' within the RESILIENCE Consortium (Religious Studies Infrastructure: Tools, Experts, Connections and Centers). PI of the individual research projects: Beyond Propaganda: Polish-Language Publishing Programme in Königsberg as a Project of Religious and Cultural Education (c. 1544-1575) (National Science Centre, no. 2020/37/N/HS2/00467) and Age of Controversy, Age of Dialogue: Bernardino Ochino and Protestant Polemical Dialogue in Sixteenth-Century Poland (Diamond Grant of the Ministry of Science and Higher Education programme, no. DI2016003546).

Wydział Polonistyki Uniwersytetu Warszawskiego

ul. Krakowskie Przedmieście 26/28

00-927 Warszawa

e-mail: wojciech.kordyzon@uw.edu.pl

\section{Bibliografia}

\section{Bazy bibliograficzne i zestawy danych}

Censimento nazionale delle edizioni italiane del XVI secolo, $<$ http://edit16.iccu.sbn.it/>

Kordyzon W., Zasób drukarski Daniela z Łęczycy (1530-1600), <https://doi.org/10.18150/VEKCVF>

Pollard A.W., Redgrave G.R., Short Title Catalogue, wyd. 2, London 1976-1991, <http://estc.bl.uk>

Verzeichnis der im deutschen Sprachbereich erschienenen Drucke des 16. Jahrhunderts (VD16), <http://www.vd16.de/>

\section{Źródla drukowane}

Akta synodów różnowierczych w Polsce, t. 1: 1550-1559, oprac. M. Sipayłło, Warszawa 1966; t. 2: 1560-1570, oprac. M. Sipayłło, Warszawa 1972

Antitrinitarische Stretigkeiten. Die tritheistische Phase (1560-1568), red. I. Dingel, oprac. K. Daugirdas, Göttingen 2013

Buschbell G., Reformation und Inquisition in Italien um die Mitte des XVI. Jahrhunderts, Paderborn 1910

Dalton H., Beiträge zur Geschichte der evangelischen Kirche in Russland, t. 3: Lasciana nebst den ältesten evang. Synodalprotokollen Polens 1555-61, Berlin 1898

Index de Rome (1557, 1559, 1564): le premiers index romains et l'index du Concile de Trente, oprac. J.M. de Bujanda, Sherbrooke 1990 
Index de Venise (1549), Venise et Milan (1554), oprac. J.M. de Bujanda, Sherbrooke 1987

Lismanino F., Brevis explicatio doctrinae de Sanctissima Trinitate, b.m.w. 1565

Negri da Bassano F., Tragedia intitolata Libero Arbitrio, 1546| 1550, oprac. C. Casalini, L. Salvarini, Roma 2014

Negri F., Della tragedia [...] intitolata Libero Arbitrio, [Bazylea] 1550

Negri F., Liberum Arbitrium tragoedia, [Genewa] 1559

Negri F., Liberum Arbitrium tragoedia, Pesclavii [i.e. Pińczów?] 1559

Trzecieski A., Carmina. Wiersze tacińskie, tłum. i oprac. J. Krókowski, Wrocław 1958

Vergerio P.P., Catalogus haereticorum aeditus Venetiis de commissione tribunalis sanctissimae inquisitionis [...] cum annotationibus Athanasii, Regiomonte Borrusiae 1556

Węgierski A., Libri quattuor Slavoniae reformatae, wyd. J. Tazbir, Warszawa 1973

Wotschke T., Die Briefwechsel der Schweizer mit den Polen, Leipzig 1908

\section{Opracowania}

Barbieri E., Un fantasma bibliografico inglese: F. Negri, “Tragedia del libero arbitrio”, Poschiavo 1547, „La Bibliofilía", 97, 1995, nr 3, s. 268-290

Barbieri E., Note sulla fortuna della “Tragedia del libero arbitrio” di F. Negri da Bassano, „Bolletino della Società di Studi Valdesi”, 181, 1997, s. 107-140

Barycz H., Daniel z Łęczycy, w: PSB, t. 4, Kraków 1938, s. 405-406

Barycz H., Lismanin Franciszek, w: PSB, t. 17, Wrocław 1972, s. 465-470

Barycz H., Meandry Lismaninowskie, „Odrodzenie i Reformacja w Polsce”, 16, 1971, s. 37-65

Brückner A., Mikołaj Rej. Studium krytyczne, Kraków 1905

Caccamo D., Eretici italiani in Moravia, Polonia, Transilvania (1558-1611). Studi e documenti, Firenze 1970

Catalogus librorum saeculi XVI qui in Bibliotheca Iagellonica Cracoviensi asservantur, t. 5, red. M. Malicki, Baden-Baden 2004

Drukarze dawnej Polski od XV do XVIII wieku, z. 5: Wielkie Księstwo Litewskie, red. A. Kawecka-Gryczowa, Wrocław 1959

Drukarze dawnej Polski, t. 1: Malopolska, cz. 1: Wiek XV-XVI, red. A. Kawecka-Gryczowa, Wrocław 1983

Gilmont J.F., Bibliographie des éditions de Jean Crespin, 1550-1572, t. 1, Verviers 1981

Hein L., Italienische Protestanten und ihr Einfluss auf die Reformation in Polen während der beiden Jahrzehnte vor dem Sandomirer Konsens, Leiden 1974

Korolko M., Seminarium Rzeczypospolitej Królestwa Polskiego. Humaniści w kancelarii królewskiej Zygmunta Augusta, Warszawa 1991

Krókowski J., Andrzej Trzecieski. Poeta-humanista i działacz reformacyjny, Warszawa 1954

Krzyżanowski J., Rej i Trzecieski, w: Mikołaj Rej w czterechsetlecie śmierci, red. T. Bieńkowski i in., Wrocław 1971, s. 7-13

Kurdybacha Ł., Zagadnienie autorstwa traktatu „De primatu papae”, „Odrodzenie i Reformacja w Polsce”, 4, 1959, s. 81-87

Quirini-Popławska D., Provana Prospero, w: PSB, t. 28, Wrocław 1985, s. 526-529

Quirini-Popławska D., Provana Traiano, w: PSB, t. 28, Wrocław 1985, s. 529-530

Ragazzini L., Francesco Negri, Baden-Baden 2006

Siniarska-Czaplicka J., Filigrany papierni położonych na obszarze Rzeczypospolitej Polskiej od poczatku XVI do XVIII wieku, Wrocław 1959

Siniarska-Czaplicka J., Papier druków tłoczonych na ziemiach województw krakowskiego i sandomierskiego w latach 1550-1700, Kwart. HKM, 14, 1976, nr 2, s. 249-274

Siniarska-Czaplicka K., Papier drukowy źródtem badań księgoznawczych, w: Dawna książka i kultura. Materiały międzynarodowej sesji naukowej z okazji pięćsetlecia sztuki drukarskiej w Polsce, red. S. Grzeszczuk, A. Kawecka-Gryczowa, Wrocław 1975, s. 132-143

Vozza V., Francesco Negri da Bassano. Aggiornamenti bio-bibliografici e nuovi percorsi di ricerca sul monaco benedettino passato alla Riforma, „Protestantesimo. Rivista della Facoltà Valdese di Teologia”, 71, 2016, nr 4, s. 359-384

Wotschke T., Francesco Lismanino, „Zeitschrift der Historischen Gesellschaft für die Provinz Posen”, 18, 1903, s. $213-332$

Zonta F., Francesco Negri l'eretico e la sua tragedia „Il libero arbitrio”, „Giornale storico della letteratura italiana", 67, 1916, nr 1, s. 265-324, 68, 1916, nr 2, s. 108-160 